\title{
Emerging Role of Fascin-1 in the Pathogenesis, Diagnosis, and Treatment of the Gastrointestinal Cancers
}

\author{
Bojana Ristic ${ }^{1, \dagger}{ }^{\dagger}$ Jonathan Kopel ${ }^{2, \dagger}$, Syed A. A. Sherazi ${ }^{3}$, Shweta Gupta ${ }^{4}$, Sonali Sachdeva ${ }^{5}$, Pardeep Bansal ${ }^{6}$, \\ Aman Ali ${ }^{7}$, Abhilash Perisetti ${ }^{8}$ and Hemant Goyal ${ }^{9, *}$ (i)
}

1 Cell Biology and Biochemistry, Texas Tech University Health Sciences Center, Lubbock, TX 79430, USA; bojana.ristic@outlook.com

2 Department of Medicine, Texas Tech University Health Sciences Center, Lubbock, TX 79430, USA; jonathan.kopel@ttuhsc.edu

3 Department of Medicine, John H Stroger Jr Hospital of Cook County, Chicago, IL 60612, USA; syedaliamir.sherazi@cookcountyhhs.org

4 Division of Hematology-Oncology, John H Stroger Jr Hospital of Cook County, Chicago, IL 60612, USA; sgupta@cookcountyhhs.org

5 Department of Cardiology, Boston University School of Medicine, Boston, MA 02118, USA; sonali.sachdeva@bmc.org

6 Department of Gastroenterology, Mercy Health-St. Vincent Medical Center, Toledo, OH 43608, USA; Pardeep79@yahoo.com

7 Department of Medicine, The Commonwealth Medical College, Scranton, PA 18510, USA; amanali786@hotmail.com

check for updates

Citation: Ristic, B.; Kopel, J.; Sherazi, S.A.A.; Gupta, S.; Sachdeva, S.; Bansal, P.; Ali, A.; Perisetti, A.; Goyal, H. Emerging Role of Fascin-1 in the Pathogenesis, Diagnosis, and Treatment of the Gastrointestinal Cancers. Cancers 2021, 13, 2536. https://doi.org/10.3390/ cancers13112536

Academic Editor: Pablo Conesa-Zamora

Received: 19 April 2021

Accepted: 19 May 2021

Published: 21 May 2021

Publisher's Note: MDPI stays neutral with regard to jurisdictional claims in published maps and institutional affiliations.

Copyright: (c) 2021 by the authors. Licensee MDPI, Basel, Switzerland. This article is an open access article distributed under the terms and conditions of the Creative Commons Attribution (CC BY) license (https:/ / creativecommons.org/licenses/by/ $4.0 /)$.
8 Department of Gastroenterology and Hepatology, The University of Arkansas for Medical Sciences, Little Rock, AR 72205, USA; aperisetti@uams.edu

9 The Wright Center for Graduate Medical Education, Scranton, PA 18510, USA

* Correspondence: doc.hemant@yahoo.com

+ The authors contributed equally to this manuscript.

Simple Summary: Gastrointestinal (GI) cancers, including esophageal, gastric, colorectal, liver, and pancreatic cancers, remain as one of the leading causes of death worldwide, with a large proportion accounting for fatalities related to metastatic disease. The active involvement of fascin- 1 in forming membrane protrusions crucial for cellular movement has been identified as an important molecular mechanism behind the phenotypic switch from the localized to the metastatic tumor. Thus, fascin- 1 expression status in the malignant tissue has been utilized as an important component in determining the patient's clinicopathological outcomes. In this review, we provide an up-to-date literature review of the role of fascin-1 in the initiation and metastatic progression of GI tract cancers, its involvement in patients' clinical outcomes, and its potential as a therapeutic target.

Abstract: Gastrointestinal (GI) cancers, including esophageal, gastric, colorectal, liver, and pancreatic cancers, remain as one of the leading causes of death worldwide, with a large proportion accounting for fatalities related to metastatic disease. Invasion of primary cancer occurs by the actin cytoskeleton remodeling, including the formation of the filopodia, stereocilia, and other finger-like membrane protrusions. The crucial step of actin remodeling in the malignant cells is mediated by the fascin protein family, with fascin- 1 being the most active. Fascin-1 is an actin-binding protein that cross-links filamentous actin into tightly packed parallel bundles, giving rise to finger-like cell protrusions, thus equipping the cell with the machinery necessary for adhesion, motility, and invasion. Thus, fascin-1 has been noted to be a key component for determining patient diagnosis and treatment plan. Indeed, the overexpression of fascin-1 in GI tract cancers has been associated with a poor clinical prognosis and metastatic progression. Moreover, fascin- 1 has received attention as a potential therapeutic target for metastatic GI tract cancers. In this review, we provide an up-to-date literature review of the role of fascin-1 in the initiation of GI tract cancers, metastatic progression, and patients' clinical outcomes.

Keywords: fascin-1; gastrointestinal (GI) tract cancers; colorectal cancer; pancreatic cancer 


\section{Introduction}

Gastrointestinal (GI) cancers, such as esophageal, gastric, colorectal, pancreatic, and liver cancers, are associated with a dismal prognosis [1]. According to the annual cancer statistics report, the digestive system will represent the second most common site for the origin of carcinogenesis in the United States (US) in 2021 [1]. Similar projections were made for the year 2020 [2]. Many GI tract cancer-related deaths are associated with metastasis; thus, patients whose cancer is disseminated onto secondary sites have worse prognosis, outcome, and reduced treatment options. The most common metastatic sites for GI tract cancers are the liver, lungs, and peritoneum $[3,4]$.

Metastasis of primary carcinoma includes the processes such as local invasion, intravasation, survival in the circulation, extravasation, and colonization (Figure 1) [5]. The local invasion requires changes in the gene expression repertoire that would yield cell migration, epithelial-to-mesenchymal transition (EMT), degradation of extracellular matrix, and angiogenesis [5].

\section{Primary Tumor}

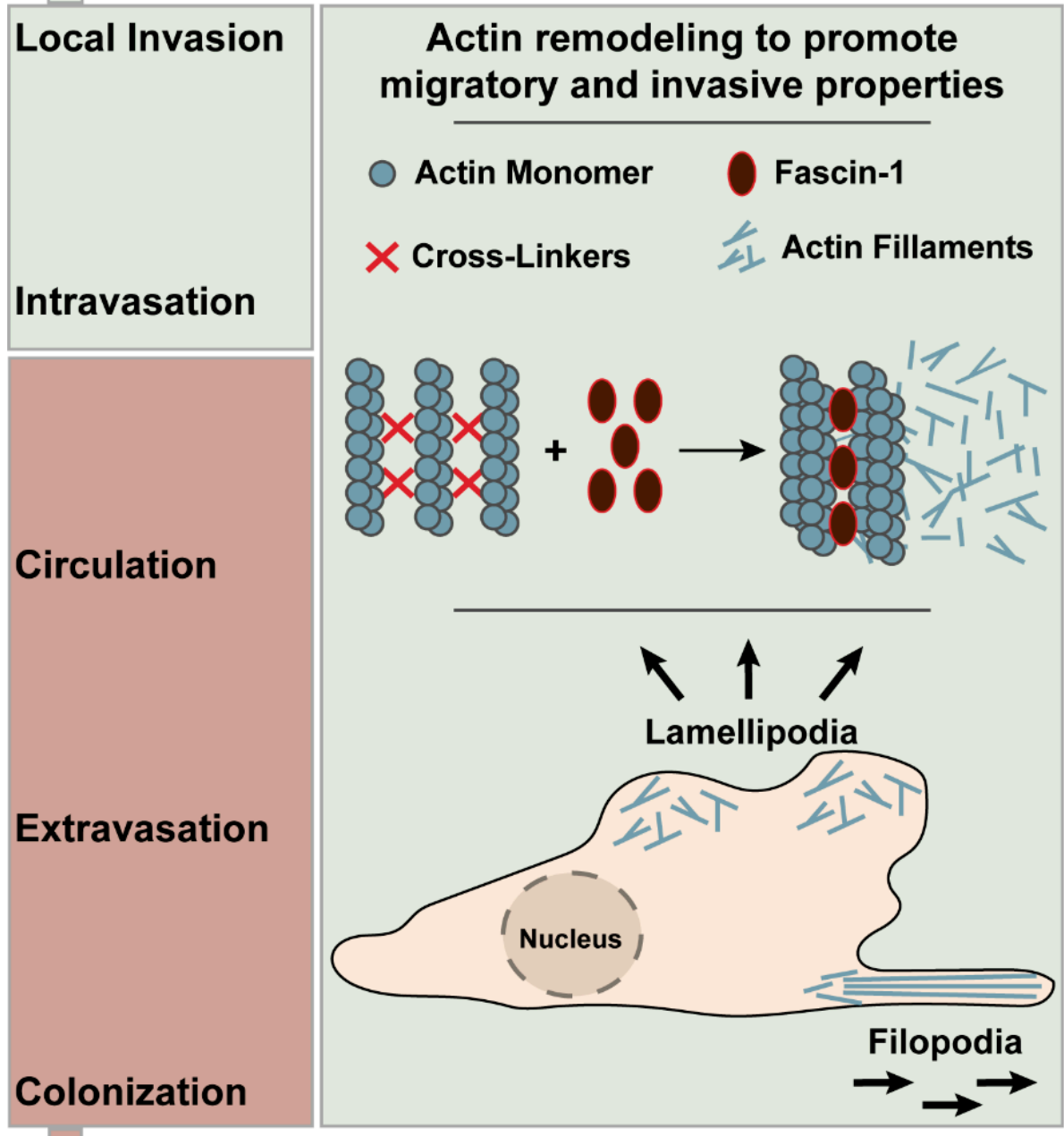

\section{Distant Metastasis}

Figure 1. Metastatic progression of the primary tumor highlighting the role of fascin-1 in actin remodeling that promotes the invasive properties of cancer.

Manipulating the expression, activity, and assembly of the cytoskeletal components such as actin, tubulin, and intermediate filaments is essential for gaining migratory and invasive properties [6]. In part, the initiation of the cell movement is due to the poly- 
merization of actin into filaments [6]. The actin filaments are packed and bundled at the leading edge of the cell to create a membrane protrusion such as filopodia and lamellipodia, which are responsible for adhesion-based cellular movement through protrusion and retraction. Filopodia are the finger-like protrusions structured by the parallel actin filament bundles. Lamellipodia are the planar protrusions composed of the branched actin filament networks [7]. Therefore, actin polymerization has been regarded as an important step for advancing carcinogenesis and has been actively studied as a therapeutic target [8]. The cross-linking and bundling of the actin filaments are, in part, facilitated by the protein family called Fascin (Figure 1) [9]. There are three isoforms in this protein family: fascin-1, fascin-2, and fascin-3 [10]. The human fascin-1 protein is a 493-amino acid-long protein and weighs $55 \mathrm{kDa}$ [10]. It is composed of four tandem $\beta$-trefoil domains giving rise to the bi-lobed structure, as visualized by the crystal structure [11]. The putative actin-binding domain (ABD)-1, which is highly conserved, is located between the amino acid residues 33 and 47, while the ABD-2 is yet to be elucidated [11].

Fascin-1 creates actin bundles by forming tight cross-links between 10-30 actin filaments [12]. This process is highly dynamic, as the dissociation and re-binding of fascin-1 to actin polymers constantly occur. These packed bundles create the architectural support for filopodia and lamellipodia [12]. Moreover, in addition to the cytoplasmic actin, fascin-1 has been implicated in stabilizing mitochondrial and nuclear actin. In this manner, it supports the cellular metabolic stress resistance and chromatin modifications [13]. Thus, fascin-1 has been portrayed as a protein with a large role in promoting cancer invasion, migration, and formation of regional and distant metastasis. Furthermore, due to its upregulation in cancer, fascin- 1 has been studied as a novel biomarker and a potential therapeutic target. There has been increased interest in utilizing fascin- 1 as a biomarker for evaluating the disease progression and assessing outcomes among gastrointestinal cancer. However, its expression, cell lines, and precise role in different types of GI cancers are unclear.

Hence in this review, we discuss the up-to-date literature on the expression pattern of fascin-1 in GI tract cancers and its implication in disease pathogenesis. Our main focus is the feasibility of utilizing fascin- 1 as the clinicopathological parameter for assessing disease stage and patient outcome. Furthermore, we will discuss the therapeutic potential of fascin-1 in GI tract carcinogenesis.

\section{Methods}

A literature search was performed using the PubMed, Embase, SCOPUS, and Web of Science databases to April 2021 to identify articles related to Fascin and gastrointestinal cancer. The inclusion criteria for our search were Fascin, liver cancer, esophageal cancer, colorectal cancer, pancreatic cancer, and gastric cancer. The exclusion criteria included oral cancer, small intestinal cancer, inflammatory bowel disease, biliary cancer, review articles, posters, commentary articles, abstracts, and articles where full text is not available. The keywords used in our search strategy included "fascin" with either of the following gastrointestinal cancers: "liver cancer", "esophageal cancer", "colorectal cancer", "pancreatic cancer", and "gastric cancer". The results of the search are shown Figure 2.

A total of 383 studies were identified after the initial search. After evaluating each result, 47 papers were excluded because they were not relevant to our topic of interest. Using our inclusion and exclusion criteria, 9 abstracts, 9 review articles, 1 commentary article, and 11 articles whose full text was not available were removed. At the end, a total of 114 articles were included for our review. 


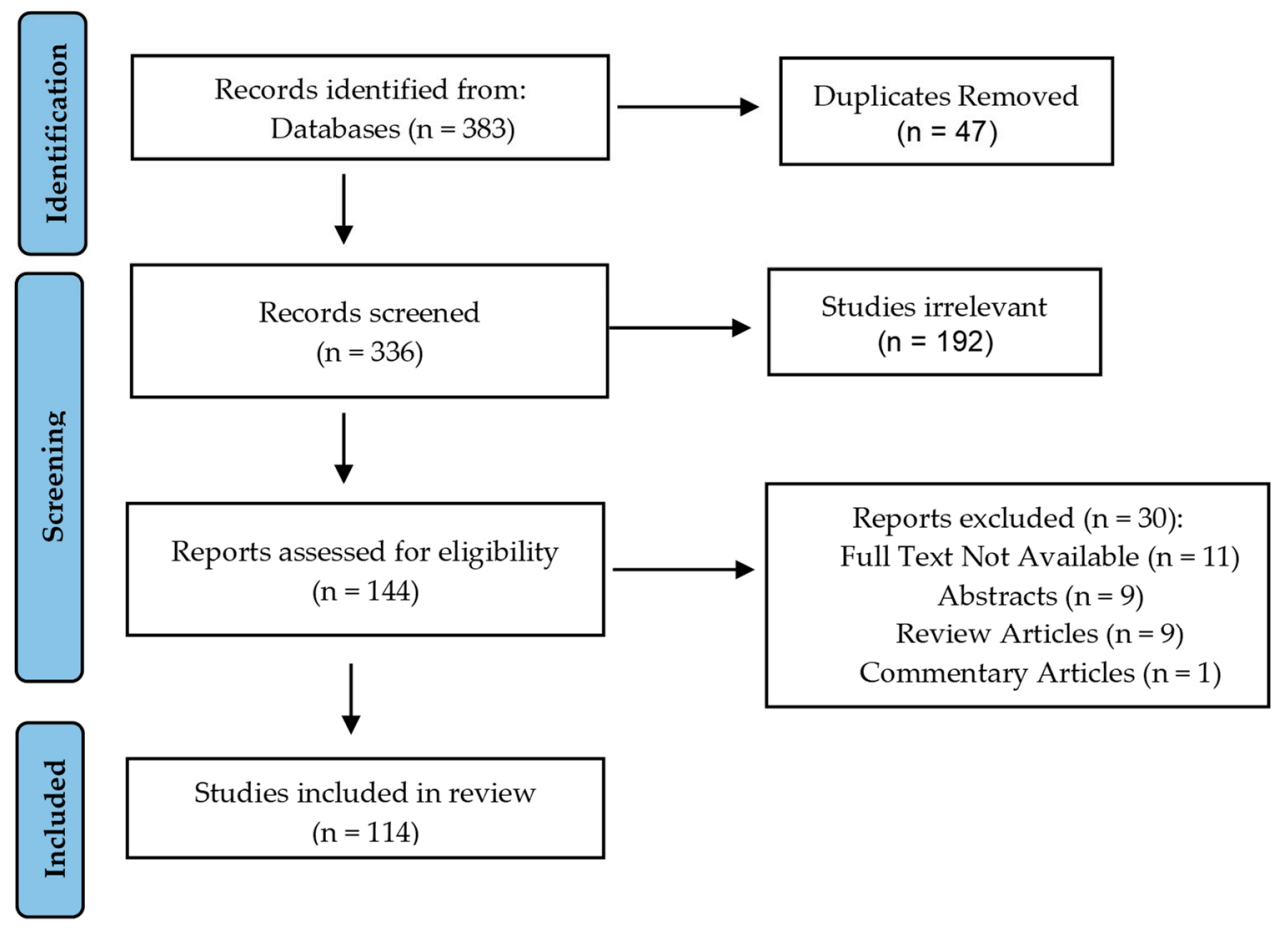

Figure 2. PRISMA guideline literature search.

\section{Fasin-1 and Esophageal Squamous Cell Carcinoma}

\subsection{Expression Pattern of Fascin-1 in ESCC and Its Potential as a Prognostic Marker}

Among gastrointestinal cancers, metastatic esophageal cancers have one of the worst five-year prognoses [14]. Recent studies have shown that fascin-1 plays an important role in the pathogenesis and metastasis of esophageal cancers. One of the reasons was a higher fascin-1 expression in esophageal squamous cell carcinoma (ESCC) in comparison to the healthy esophageal epithelium (Table 1) [15-19]. Furthermore, fascin-1 expression was seen to increase progressively from the normal esophageal epithelium to invasive esophageal cancers [16-19]. High levels of fascin-1 were correlated with cell proliferation, lymph node invasion, and distant metastasis [19,20].

Table 1. Overexpression pattern of fascin-1 in GI tract cancers as an unfavorable prognostic and diagnostic marker for advanced carcinogenesis, regional and distant metastases, and overall survival.

\begin{tabular}{|c|c|c|c|c|c|c|c|}
\hline \multirow{2}{*}{$\begin{array}{l}\text { Type of } \\
\text { Cancer }\end{array}$} & \multirow[b]{2}{*}{ Refs. } & \multirow[b]{2}{*}{ Methods } & \multicolumn{4}{|c|}{ Correlation Between High Fascin-1 Expression and: } & \multirow{2}{*}{$\begin{array}{l}\text { Independent } \\
\text { Factor }\end{array}$} \\
\hline & & & $\begin{array}{l}\text { Lymph Node } \\
\text { Metastasis }\end{array}$ & $\begin{array}{c}\text { Distant } \\
\text { Metastasis }\end{array}$ & $\begin{array}{l}\text { Reduced } \\
\text { Survival }\end{array}$ & Other Clinicopathological Outcomes & \\
\hline \multirow{4}{*}{$\begin{array}{l}\text { Esophageal } \\
\text { Cancer }\end{array}$} & [18] & $\begin{array}{c}\text { IHC, } \\
\text { rt-PCR, WB }\end{array}$ & + & $\mathrm{N} / \mathrm{A}$ & $\mathrm{N} / \mathrm{A}$ & $\begin{array}{l}\text { Stage-dependent progression of ESCC } \\
\text { Cell proliferation }\end{array}$ & $\mathrm{N} / \mathrm{A}$ \\
\hline & [19] & $\mathrm{IHC}$ & + & $\mathrm{N} / \mathrm{A}$ & + & Tumor stage (III and IV) & + \\
\hline & [20] & $\mathrm{IHC}$ & + & + & $\mathrm{N} / \mathrm{A}$ & $\begin{array}{l}\text { Tumor differentiation } \\
\text { Poor differentiation } \\
\text { T4 stage }\end{array}$ & $\mathrm{N} / \mathrm{A}$ \\
\hline & [21] & IHC & + & + & + & Advanced tumor & + \\
\hline \multirow{2}{*}{$\begin{array}{l}\text { Gastric } \\
\text { Adenocar- } \\
\text { cinoma }\end{array}$} & {$[22]$} & rt-qPCR & + & + & $\mathrm{N} / \mathrm{A}$ & $\begin{array}{l}\text { Tumor differentiation } \\
\text { Advanced tumor }\end{array}$ & $\mathrm{N} / \mathrm{A}$ \\
\hline & [23] & $\mathrm{IHC}$ & + & $\mathrm{N} / \mathrm{A}$ & + & $\begin{array}{c}\text { Tumor size } \\
\text { Depth of invasion } \\
\text { Lymphatic and venous invasion } \\
\text { UICC staging }\end{array}$ & N/A \\
\hline
\end{tabular}


Table 1. Cont.

\begin{tabular}{|c|c|c|c|c|c|c|c|}
\hline \multirow{2}{*}{$\begin{array}{l}\text { Type of } \\
\text { Cancer }\end{array}$} & \multirow[b]{2}{*}{ Refs. } & \multirow[b]{2}{*}{ Methods } & \multicolumn{4}{|c|}{ Correlation Between High Fascin-1 Expression and: } & \multirow{2}{*}{$\begin{array}{l}\text { Independent } \\
\text { Factor }\end{array}$} \\
\hline & & & $\begin{array}{l}\text { Lymph Node } \\
\text { Metastasis }\end{array}$ & $\begin{array}{c}\text { Distant } \\
\text { Metastasis }\end{array}$ & $\begin{array}{l}\text { Reduced } \\
\text { Survival }\end{array}$ & Other Clinicopathological Outcomes & \\
\hline \multirow{4}{*}{$\begin{array}{l}\text { Gastric } \\
\text { Adenocar- } \\
\text { cinoma }\end{array}$} & [24] & $\mathrm{IHC}$ & + & - & + & $\begin{array}{c}\text { Extent of primary tumor } \\
\text { Age } \\
\text { Serosal invasion } \\
\text { Histopathological grading } \\
\text { TNM staging } \\
\text { Recurrence }\end{array}$ & - \\
\hline & [25] & IHC & $\mathrm{N} / \mathrm{A}$ & $\mathrm{N} / \mathrm{A}$ & + & $\begin{array}{c}\text { TNM staging } \\
\text { High-grade histopathological differentiation }\end{array}$ & $\mathrm{N} / \mathrm{A}$ \\
\hline & [26] & IHC & $\mathrm{N} / \mathrm{A}$ & $\mathrm{N} / \mathrm{A}$ & + & Tumor size & + \\
\hline & [27] & IHC & + & $\mathrm{N} / \mathrm{A}$ & + & $\begin{array}{c}\text { High clinical stage } \\
\text { High T stage } \\
\text { Lymphovascular invasion } \\
\text { The intestinal type of Lauren classification }\end{array}$ & + \\
\hline \multirow{12}{*}{$\begin{array}{l}\text { Colorectal } \\
\text { Adenocar- } \\
\text { cinoma }\end{array}$} & [28] & $\mathrm{IHC}$ & + & + & + & $\begin{array}{l}\text { Tumor grade and stage } \\
\text { Mucinous differentiation } \\
\text { Extranodal tumor extension } \\
\text { Increased recurrence rate } \\
\text { Cancer progression }\end{array}$ & + \\
\hline & [29] & $\mathrm{IHC}$ & $\mathrm{N} / \mathrm{A}$ & $\mathrm{N} / \mathrm{A}$ & $\mathrm{N} / \mathrm{A}$ & $\begin{array}{l}\text { Tumor size } \\
\text { Histological type } \\
\text { Degree of dysplasia }\end{array}$ & $\mathrm{N} / \mathrm{A}$ \\
\hline & [30] & $\begin{array}{l}\text { IHC and } \\
\text { qPCR }\end{array}$ & + & + & N/A & High expression in stage III/IV CRC & $\mathrm{N} / \mathrm{A}$ \\
\hline & [31] & IHC & $\mathrm{N} / \mathrm{A}$ & $\mathrm{N} / \mathrm{A}$ & + & Worse prognosis for stage III/IV patients & $\mathrm{N} / \mathrm{A}$ \\
\hline & [32] & IHC & $\mathrm{N} / \mathrm{A}$ & $\mathrm{N} / \mathrm{A}$ & + & Advanced tumor depth & + \\
\hline & [33] & $\mathrm{IHC}$ & $\mathrm{N} / \mathrm{A}$ & N/A & $\mathrm{N} / \mathrm{A}$ & $\begin{array}{c}\text { Advanced dysplasia } \\
\text { High-grade histopathological differentiation } \\
\text { Advanced T stage }\end{array}$ & $\mathrm{N} / \mathrm{A}$ \\
\hline & [34] & IHC & + & $\mathrm{N} / \mathrm{A}$ & + & Invasive tumors and advanced cancer stage & $\mathrm{N} / \mathrm{A}$ \\
\hline & [35] & $\mathrm{IHC}$ & $\mathrm{N} / \mathrm{A}$ & $\mathrm{N} / \mathrm{A}$ & $\mathrm{N} / \mathrm{A}$ & $\begin{array}{l}\text { Adenocarcinoma type without mucosal } \\
\text { component }\end{array}$ & $\mathrm{N} / \mathrm{A}$ \\
\hline & [36] & $\mathrm{IHC}$ & $\mathrm{N} / \mathrm{A}$ & $\mathrm{N} / \mathrm{A}$ & + & $\begin{array}{l}\text { Increased tumor budding } \\
\text { Systemic inflammation } \\
\text { Decreased memory T-cells }\end{array}$ & $\mathrm{N} / \mathrm{A}$ \\
\hline & [37] & IHC & + & + & + & $\begin{array}{l}\text { Progressive anatomic disease extent } \\
\text { Higher T classification } \\
\text { High-grade tumors } \\
\text { Increased vascular invasion }\end{array}$ & + \\
\hline & [38] & $\mathrm{IHC}$ & $\mathrm{N} / \mathrm{A}$ & + & + & Increased recurrence rate & + \\
\hline & [39] & IHC & $\mathrm{N} / \mathrm{A}$ & $\mathrm{N} / \mathrm{A}$ & $\mathrm{N} / \mathrm{A}$ & High expression in anti-EGFR resistant CRC & $\mathrm{N} / \mathrm{A}$ \\
\hline \multirow{3}{*}{$\begin{array}{l}\text { Hepatocell- } \\
\quad \text { ular } \\
\text { Carcinoma }\end{array}$} & [40] & IHC & + & + & + & $\begin{array}{l}\text { Histological differentiation } \\
\text { Metastasis }\end{array}$ & $\mathrm{N} / \mathrm{A}$ \\
\hline & [41] & $\mathrm{IHC}$ & + & + & + & $\begin{array}{c}\text { Advanced Differentiation } \\
\text { Tumor size } \\
\text { Regional and distant metastasis }\end{array}$ & $\mathrm{N} / \mathrm{A}$ \\
\hline & [42] & $\mathrm{IHC}$ & $\mathrm{N} / \mathrm{A}$ & $\mathrm{N} / \mathrm{A}$ & $\mathrm{N} / \mathrm{A}$ & $\begin{array}{l}\text { No correlation with clinicopathological } \\
\text { parameters }\end{array}$ & $\mathrm{N} / \mathrm{A}$ \\
\hline
\end{tabular}


Table 1. Cont.

\begin{tabular}{|c|c|c|c|c|c|c|c|}
\hline \multirow{2}{*}{$\begin{array}{l}\text { Type of } \\
\text { Cancer }\end{array}$} & \multirow[b]{2}{*}{ Refs. } & \multirow[b]{2}{*}{ Methods } & \multicolumn{4}{|c|}{ Correlation Between High Fascin-1 Expression and: } & \multirow{2}{*}{$\begin{array}{l}\text { Independent } \\
\text { Factor }\end{array}$} \\
\hline & & & $\begin{array}{l}\text { Lymph Node } \\
\text { Metastasis }\end{array}$ & $\begin{array}{c}\text { Distant } \\
\text { Metastasis }\end{array}$ & $\begin{array}{l}\text { Reduced } \\
\text { Survival }\end{array}$ & Other Clinicopathological Outcomes & \\
\hline \multirow{8}{*}{$\begin{array}{l}\text { Pancreatic } \\
\text { Adenocar- } \\
\text { cinoma }\end{array}$} & [43] & IHC & $\mathrm{N} / \mathrm{A}$ & $\mathrm{N} / \mathrm{A}$ & $\mathrm{N} / \mathrm{A}$ & Advanced PanIN, stage-dependent & $\mathrm{N} / \mathrm{A}$ \\
\hline & [44] & IHC & + & + & + & $\begin{array}{c}\text { Advanced tumor grade } \\
\text { Advanced T stages } \\
\text { Histological grade and clinical stages }\end{array}$ & $\mathrm{N} / \mathrm{A}$ \\
\hline & [45] & IHC & $\mathrm{N} / \mathrm{A}$ & $\mathrm{N} / \mathrm{A}$ & + & $\begin{array}{l}\text { Increased recurrence rate } \\
\text { Increased vascular invasion }\end{array}$ & $\mathrm{N} / \mathrm{A}$ \\
\hline & [46] & IHC & N/A & N/A & $\mathrm{N} / \mathrm{A}$ & Advanced PanIN, stage-dependent & $\mathrm{N} / \mathrm{A}$ \\
\hline & [47] & IHC & $\mathrm{N} / \mathrm{A}$ & $\mathrm{N} / \mathrm{A}$ & + & Advanced tumor grade & $\mathrm{N} / \mathrm{A}$ \\
\hline & [48] & IHC & $\mathrm{N} / \mathrm{A}$ & $\mathrm{N} / \mathrm{A}$ & + & $\begin{array}{c}\text { Histological grade } \\
\text { American Joint Committee on Cancer Stage }\end{array}$ & N/A \\
\hline & [49] & $\mathrm{IHC}$ & $\mathrm{N} / \mathrm{A}$ & $\mathrm{N} / \mathrm{A}$ & $\mathrm{N} / \mathrm{A}$ & N/A: High background with anti-fascin-1 & $\mathrm{N} / \mathrm{A}$ \\
\hline & [50] & $\mathrm{IHC}$ & $\mathrm{N} / \mathrm{A}$ & $\mathrm{N} / \mathrm{A}$ & $\mathrm{N} / \mathrm{A}$ & $\begin{array}{l}\text { N/A: Antibody with high specificity but } \\
\text { low sensitivity }\end{array}$ & $\mathrm{N} / \mathrm{A}$ \\
\hline
\end{tabular}

In addition, elevated fascin-1 mRNA and protein levels were associated with the ESCC histological type and tumor stages III and IV [19]. Patients with high fascin-1 status in ESCC exhibited a significant reduction in overall and disease-free survival parameters. Therefore, fascin-1 was labeled as an unfavorable prognostic tool for ESCC overall survival [19].

Staining for other oncogenic proteins alongside fascin-1 in ESCC improved prognostic predictions (Figure 3) [21,51-53]. Performing immunohistochemistry (IHC) with epidermal growth factor receptor (EGFR), specificity protein 1 (Sp1), and fascin-1 antibodies served as a good prognostic tool for ESCC patient survival [21]. They proposed that this approach could aid in more accurate clinical risk stratification [21]. Furthermore, Tan and colleagues included determination of fascin-1 protein status as a critical component of the diagnostic model they developed [51]. These studies were supported by the systematic review performed by Wang et al. [52]. Lastly, fascin-1 auto-antibody levels were elevated in the serums of early-stage ESCC patients [54]. Although these studies identified fascin-1 as a promising prognostic tool for ESCC, further investigations are needed to test the therapeutic potential of this protein in ESCC.

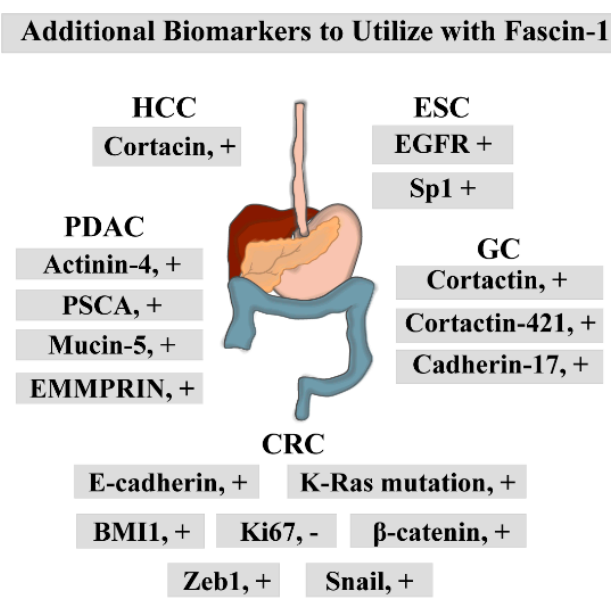

Figure 3. The biomarkers that can be utilized alongside fascin-1 IHC to improve the diagnostic potential of fascin-1. +, positive correlation; -, negative correlation.

\subsection{Outcome of Fascin-1 Overexpression in ESCC}

The contribution of fascin- 1 to the aggressive phenotype of ESCC was deduced by performing the loss of function studies via RNAi technology and the subsequent network 
analyses of gene expression [55] (Figure 4). When fascin-1 was silenced in the ESCC cell line, in vitro and in vivo experiments demonstrated that the cells acquired lower proliferation, invasive and migratory capacities [56,57]. The degradation of fascin-1 elicited a dramatic decrease of c-erbB-2, $\beta$-catenin, MMP-2, and MMP-9 protein levels [56]. Furthermore, Ortiz et al. showed that loss of fascin-1 produced cell growth inhibition and the detachment of cells from the collagen-coated plate. Furthermore, when they tracked tumor formation in vivo, they discovered that the growth of tumors with low fascin-1 expression significantly declined [58]. Lastly, silencing of fascin-1 in ESCC leads to downregulation of Cysteinerich, angiogenic inducer 61 (CYR61) and Connective tissue growth factor (CTGF) in the TGF $\alpha$-dependent manner [57]. The reconstitution of these proteins in the fascin-1 silenced cell line resulted in higher proliferative and invasive capacities [57]. Therefore, fascin-1 interacted with the complex protein network to influence esophageal carcinogenesis.

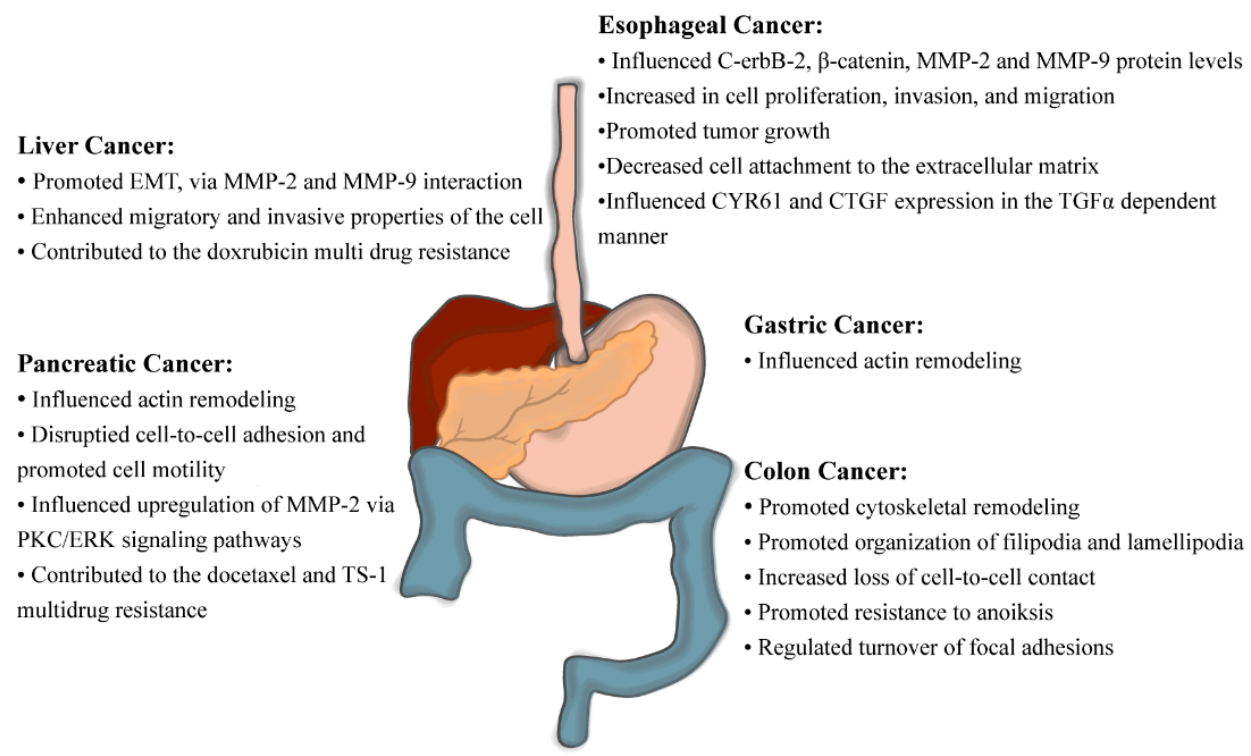

Figure 4. Fascin-1-associated cellular changes that promote GI tract carcinogenesis. These observations were made via fascin-1 loss-of-function or gain-of-function experiments.

\subsection{Regulation of Fascin-1 Expression in ESCC}

By examining the fascin-1 promoter in normal and ESCC cells, Hou et al. discovered that fascin-1 overexpression was not dictated by the promoter methylation, but that it was likely to occur due to its promoter transactivation [59]. On this note, fascin-1 was regulated by the Sp1, which acted as its activator (Figure 4) [60]. The signal for this transcriptional upregulation was initiated by the epidermal growth factor (EGF), and it was relayed by the Erk1/2 signaling cascade [60]. Furthermore, on the post-transcriptional level, fascin-1 mRNA stability in ESCC depended on the tumor suppressor microRNAs and the long noncoding RNA, TTN-AS1 [61-65]. miR-145, miR-143 miR-133a, and miR-133b interacted with the $3^{\prime}$ UTR of fascin-1 mRNA and resulted in a significant decrease in its expression, which in turn inhibited ESCC cell growth and invasion [61-64]. Long noncoding RNA, TTN-AS1, however, stabilized the fascin-1 mRNA in ESCC by sponging miR-133b [65].

Fascin-1 protein possesses four phosphorylation sites (tyrosine 23, serine 38, serine 39, and serine 274), which regulate its function and further affect cell behavior and filopodia formation in ESCC [66]. Phosphorylation on these sites had an inhibitory effect on fascin-1 function, and it decreased the extent of cell migration and filopodia formation in ESCC [66]. Furthermore, while high fascin-1 mRNA and protein levels were correlated to the unfavorable outcome of ESCC, elevation in phosphorylated fascin-1 on Ser-39 was associated with the improved patient prognosis [67]. Kinases that mediate this process are yet to be determined $[66,67]$. 


\section{Fascin-1 and Gastric Carcinoma}

\subsection{Expression Pattern of Fascin-1 in GC and Its Potential as a Prognostic Marker}

Investigations that used tissue microarray and IHC found that fascin-1 mRNA and protein levels were significantly upregulated in gastric carcinoma (GC) $[22,68]$. Fascin- 1 was primarily localized in the cytoplasm of the vascular endothelial cells, lymphocytes, smooth muscle cells, adenomas, and adenocarcinoma cells [23]. Moreover, its expression was predominantly confined to the tumor edges at the sites with active actin remodeling [24].

High fascin-1 expression in GC positively correlated with tumor size, depth of invasion, lymphatic and venous invasion, lymph node metastasis, and UICC staging (Table 1). Furthermore, fascin-1 was more expressed in older GC patients [23]. Fascin-1 overexpression pattern was associated with more advanced TNM stages and poorly differentiated tumors [22,25]. Moreover, it was related to the GC tumor size [26]. Kim and colleagues found a positive correlation between high fascin-1 expression in GC and high clinical-stage, high T stage, and the intestinal type of Lauren classification [27]. They also correlated increased fascin-1 levels with nodal metastasis and lymphovascular invasion [27]. The same correlation between fascin- 1 expression and the extent of the primary tumor, age, serosal invasion, positive lymph node metastasis, histopathological grading, TNM stage, and cancer recurrence was noted in an additional independent study [24]. However, there was no significant association with the occurrence of distant metastasis in their analyses and the classification of the histological tumor subtypes according to the Lauren's criteria, such as intestinal or diffuse type of GC [24]. The systemic meta and bioinformatic analyses performed by Zheng et al. noted similar association trends between fascin-1 expression and poor clinicopathological outcomes [68]. Lastly, high fascin-1 levels, along with increased SMAD-4 expression, were associated with worse outcomes of the diffuse type of Epstein-Barr virus (EBV)-associated gastric cancer [69]. Patients with upregulated fascin-1 in GC had poorer outcomes, with significantly reduced overall and disease-free survival $[23-27,68,69]$. Fascin-1 has also labeled the independent variable in multivariate analysis $[26,27]$. Therefore, these studies proposed that fascin- 1 can be employed as a diagnostic and prognostic marker for GC and a valuable prediction tool for clinical outcome of patients. Lastly, performing dual staining with other GC oncogenes, such as cortactin, cortactin-421, and cadherin-17, could provide more precise clinicopathologic features of gastric carcinogenesis (Figure 3) $[23,25,26]$.

\subsection{Regulation of Fascin-1 Expression in GC}

The oncogenic protein, zinc finger protein 139 (ZNF139), was labeled as a potent fascin-1 activator in GC (Figure 5) [70]. Suppression of ZNF139 with RNA interference technology significantly downregulated fascin-1 mRNA and protein levels in GC cell lines [70]. Furthermore, Kim et al. discovered that galectin-1, a $\beta$-galactoside-binding protein, induced fascin-1 mRNA and protein levels [71]. It did so by stabilizing the GSK$3 \beta / \beta$-catenin/TCF4 complex and chaperoning it into the nucleus [71]. Fascin- 1 expression was also activated by the oncogenic cytokine, transforming growth factor (TGF)- $\beta$ [72,73]. The TGF- $\beta$-elicited upregulation of fascin- 1 heavily depended on the activated SMAD3 signaling pathway, which was observed by the increased phosphorylation of SMAD3 [72]. Moreover, Fu et al. discovered that JNK and Erk signaling pathways were indispensable for TGF- $\beta$-directed activation of fascin-1 [73]. The chemical inhibition of these pathways abrogated TGF- $\beta$-elicited upregulation of fascin-1 [73]. TGF- $\beta$ was overexpressed in GC and was secreted by the tumor microenvironment to promote invasion and metastasis [73]. This ability was heavily dependent on increased fascin-1 levels [73]. Indeed, the GC cell line treated with TGF- $\beta$ but had silenced fascin- 1 did not show migratory and invasive properties [73]. The reverse was true upon fascin-1 reconstitution [73]. In GC, fascin-1 was also transcriptionally activated by signal transducer and activator of transcription (STAT)-3 [74,75]. The stimulating signal came either via interleukin (IL)-6 or Fas signaling pathways $[74,75]$. The interaction of IL- 6 with its receptor transduced the activation signal by recruiting NfkB and STAT3 to the fascin-1 promoter [74]. Upregulation of fascin-1 
mRNA and protein along the Fas/STAT3 signaling pathway increased cell migration in vitro and GC metastasis to the lungs in vivo [75]. Thus, IL-6/STAT3/NfKB/fascin- 1 and Fas/STAT3/fascin-1 axes were identified as novel therapeutic targets for advanced GC and metastases [74,75]. Furthermore, the authors suggested that inhibitors that target IL-6, Fas, and STAT3 signaling pathways could abolish fascin- 1 expression and could be used as an adjuvant treatment strategy for GC $[74,75]$.

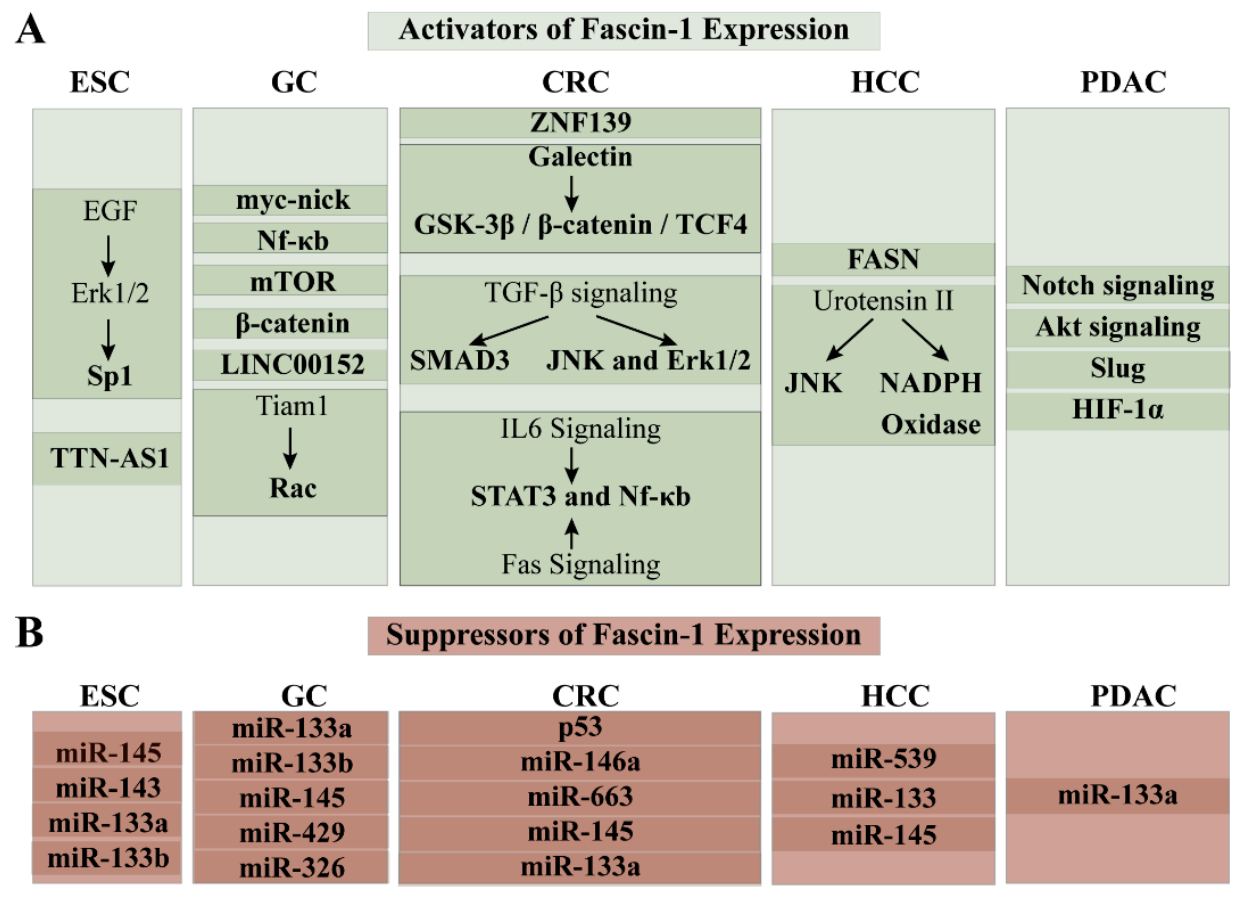

Figure 5. Regulators of the fascin-1 expression in GI tract cancers. (A) Factors that elicit upregulation of fascin-1 expression; (B) Factors that elicit downregulation of fascin-1 expression.

MicroRNA, such as miR-133a, miR-133b, miR-145, miR-326, and miR-429, were labeled as potent fascin-1 post-transcriptional suppressors [76-80]. In its $3^{\prime}$ UTR region, fascin1 mRNA possesses binding elements for miR-133a, miR-133b, miR-145, miR-326, and miR-429 [76-80]. Upon successful association between the miRNAs and their binding elements in the $3^{\prime}$ UTR region of the target, they elicited degradation of fascin-1 mRNA and subsequent reduction in its protein levels [76-80]. These studies also showed that the miRNAs in question are downregulated in GC and suggested that their loss resulted in fascin-1 overexpression in GC [76-80]. Indeed, reconstitution of miR-133b and miR-326 in GC cell lines elicited drastic reduction of fascin-1 mRNA and protein and led to the inhibition of proliferation, migration, and invasion $[76,80]$. Thus, activating these miRNAs could serve as a potential therapeutic agent.

\section{Fascin-1 and Colorectal Cancer (CRC)}

\subsection{Expression Pattern of Fascin-1 in CRC and Its Potential as a Prognostic Marker}

IHC of resected sporadic and familial colorectal adenomas and adenocarcinomas showed increased fascin-1 expression in comparison to the healthy colon, where the basal expression was minimal $[28,29,81]$. Fascin- 1 was localized in the cytoplasm at the invasive front of tumor cells and the endothelial cells of tumor blood vessels [30]. Interestingly, fascin- 1 expression was focal during the initial stages, but diffused in more advanced forms of CRC [31]. Moreover, this protein was overexpressed in inflammation-driven colon cancer in a manner that corresponded with the disease severity and progression [82]. Its expression was also associated with the onco-proteins expression of Epstein-Barr virus and 
human papillomaviruses, which were present in 36.27 and $53.84 \%$ of CRC tissues in the Syrian population, respectively [83,84].

High immunoreactivity of fascin-1 was positively correlated with the poor clinicopathological outcomes of CRC $[85,86]$. High fascin-1 expression was associated with advanced dysplasia, greater tumor burden, and tumor depth $[32,33,85,86]$. Moreover, elevated fascin- 1 levels were related to a higher $\mathrm{T}$ classification and advanced tumor stage, with the highest expression level recorded in stages III/IV of CRC [34,85,86]. Furthermore, tumors that possessed high fascin-1 levels exhibited a greater capacity to invade regional lymph nodes and develop extranodal tumor extensions [85,86]. Furthermore, they were more likely to disseminate and metastasize onto distant secondary sites [85,86]. The presence of fascin- 1 in the secondary tumor metastasis was not recorded [30]. Mucinous differentiation of tumor and its classification into the histological subtypes was also related to the fascin- 1 expression $[33,35]$. In addition, Roseweir and colleagues noted that the increased expression levels of the EMT markers and fascin- 1 were associated with tumor budding, higher systemic inflammation, and fewer memory T-cells [36]. CRC patients whose surgical resection showed high fascin-1 levels increased the likelihood of cancer recurrence $[85,86]$. Moreover, they exhibited lower overall and disease-free survival rates $[32,34,37]$. Lastly, fascin- 1 was defined as a CRC independent factor in multivariate analysis $[32,37,38]$.

These investigations suggested that fascin- 1 could be utilized as an effective diagnostic and prognostic tool (Table 1). Namely, fascin-1 could serve as a poor prognostic marker for advanced and more aggressive CRC [31,33,37,85]. Furthermore, it was proposed to serve as a poor prognostic marker for regional and distant metastasis $[34,37,38]$. Testing its expression levels in biopsies and surgical resections could predict the patient's survival rate and the possibility of cancer recurrence [32,34,37,38]. High expression of fascin- 1 was also detected in tumors that harbored $\mathrm{K}$-Ras mutation, which is resistant to the available anti-epidermal growth factor receptor (anti-EGFR) CRC therapy [39]. Therefore, Kocer et al. suggested that determination of fascin-1 status along with K-Ras mutations in tumors could aid in a more precise diagnosis of anti-EGFR resistant CRC [39]. Lastly, several studies tested additional markers that can be utilized in conjunction with fascin- 1 to give a more precise diagnosis and prognosis (Figure 3). Namely, staining with BMI1 proto-oncogene, polycomb ring finger (BMI1) alongside fascin-1 served as a better prognostic factor for overall survival [87]. Fascin-1 staining in more advanced CRC was inversely correlated with staining for proliferation marker, Ki67 [31]. A study performed by Roseweir and colleagues found that fascin-1 is a valuable prognostic tool that can stratify patients' survival rates when combined with other EMT markers, such as E-cadherin, Snail, Zeb1, and $\beta$-catenin [36]. Finally, incorporating IHC scores for fascin-1 and resistin was instrumental in evaluating CRC patients' overall survival [81].

\subsection{Outcome of Fascin-1 Overexpression and Suppression in CRC}

It is evident from the experiments of manipulated fascin-1 expression in vivo and in vitro that fascin-1 is a component of colorectal carcinogenesis that defines its migration and invasive properties (Figure 4). Schoumacher et al. conditionally overexpressed fascin1 in the mouse model of CRC, where unregulated cell proliferation was elicited by the Apc gene mutation [88]. They observed in vivo that overexpression of fascin-1 increased intestinal tumor burden, earlier disease onset, and reduced survival upon fascin-1 overexpression [88]. It was rationalized by the observation that fascin-1 promotes cytoskeletal remodeling, loss of cell-to-cell contact, and active organization of filipodia and lamellipodia in CRC cell line, thus equipping dysplastic cells for movement and invasion [29,30,89]. Kanda and colleagues made similar observations in the inflammation-associated colon cancer cell model and further discovered that fascin-1 is implicated in the resistance to cell programmed death driven by the loss of cell-to-cell adhesion, anoiksis [90]. Furthermore, abolishing fascin-1 expression via RNA interference technology in CRC cell lines elicited al- 
terations in the finger-like cell protrusions, interrupted proper turnover of focal adhesions, and inhibited cell migration, yielding less invasive and metastatic xenograft tumors [91,92].

\subsection{Fascin-1 as a Therapeutic Target in CRC}

A handful of newly synthesized and re-purposed therapeutics have been tested as active fascin- 1 inhibitors and suppressors of colorectal carcinogenesis. Montoro-García et al. discovered that compound G2 inhibited fascin-1-directed actin remodeling (Table 2) [93]. This action elicited the collapse of filopodia and minimized migration and invasive properties of CRC in vitro and in vivo [93]. Administration of $100 \mathrm{mg}$ of $\mathrm{G} 2$ per $\mathrm{kg}$ of body weight did not elicit any significant toxic effect to the athymic nude mice [94]. The possible side effects of this drug are yet to be investigated. Furthermore, Mahmoud and colleagues synthesized novel polymethoxylated chalcones and their analogs and examined their therapeutic potential against the CRC with K-Ras mutation [95]. They found that compounds 3 and 14 successfully downregulated fascin-1, abolished EMT, and reduced cancer cell invasion and metastasis [95]. However, additional studies are necessary to investigate the efficacy of these compounds in vivo, as well as to address any potential side effects. Moreover, antidepressant imipramine was identified as a novel fascin-1 inhibitor (Table 2) [96]. Imipramine effectively reduced fascin- 1 mRNA and protein levels, interrupted cytoskeletal remodeling and filopodia formation, and prevented metastasis in a dose-dependent manner [96]. The case-control study that consisted of 31,953 cancer cases and 61,591 controls found that the usage of imipramine may lead to the prevention of colorectal cancer and glioma [97]. At the moment, there are two ongoing clinical trials investigating the effects of imipramine on recurring glioblastoma (NCT04863950) and $\mathrm{ER}^{+}$and triple-negative breast cancer (NCT03122444). Lastly, raltegravir which is an FDA-approved inhibitor of human immunodeficiency virus-1 integrase, elicited the disorganization of actin cytoskeleton, and disrupted the invasive and metastatic properties of the cell by directly targeting fascin1 [98]. This experiment was carried out in human CRC cell lines HCT-116 and DLD-1, and in zebrafish model of invasion [98]. Its safety and efficacy is yet to be examined in human CRC treatment.

Table 2. Description of the experiments that examined the inhibitory effects of different compounds on fascin- 1 expression in colorectal cancer, hepatocellular carcinoma, and pancreatic adenocarcinoma.

\begin{tabular}{|c|c|c|c|c|c|}
\hline Compound & Cancer Type & Cell Lines & In Vivo Models & Clinical Trial Data & Ref. \\
\hline Compound G2 & \multirow{4}{*}{ Colorectal Cancer } & HCT-116, DLD-1 & $\begin{array}{l}\text { Zebrafish model of } \\
\text { invasion }\end{array}$ & No & [93] \\
\hline $\begin{array}{l}\text { Polymethoxylated } \\
\text { Chalcones 3/14 }\end{array}$ & & $\begin{array}{c}\text { HCT-116, LoVo, } \\
\text { HT-29, NCE-1 E6/E7 }\end{array}$ & Unknown & No & [95] \\
\hline Imipramine & & $\begin{array}{c}\text { SW-480, DLD-1, } \\
\text { HCT-15, HCT-116, } \\
\text { HT-29, LS174T, } \\
\text { SW-620, LoVo }\end{array}$ & $\begin{array}{l}\text { Zebrafish model of } \\
\text { invasion }\end{array}$ & No & [96] \\
\hline Raltegravir & & HCT-116, DLD-1 & $\begin{array}{l}\text { Zebrafish model of } \\
\text { invasion }\end{array}$ & No & [98] \\
\hline $\begin{array}{l}\text { Natural Killer } \\
\text { Lysine }\end{array}$ & \multirow{2}{*}{ Hepatocellular Carcinoma } & $\begin{array}{l}\text { SMMC-7721, } \\
\text { 97-H, HepG2 }\end{array}$ & Unknown & No & [99] \\
\hline Doxycycline & & Unknown & $\begin{array}{c}\text { Thiocetamide HCC } \\
\text { animal model }\end{array}$ & No & [100] \\
\hline Salinomycin & Pancreatic Adenocarcinoma & $\begin{array}{l}\text { AsPC-1, Colo357, } \\
\text { MiaPaCa-2, } \\
\text { PANC-1, Panc02 }\end{array}$ & $\begin{array}{c}\text { Orthotopic } \\
\text { injection of Panc02 } \\
\text { in } \mathrm{C} 57 \mathrm{Bl} / 6 \text { mice }\end{array}$ & No & [101] \\
\hline
\end{tabular}




\subsection{Regulation of Regulation of Fascin-1 in CRC5}

Knowledge of the transcriptional, post-transcriptional, and post-translational regulation of fascin-1 in CRC can be utilized to develop new therapeutic or to re-purpose the already approved FDA treatment regimens (Figure 5). Myc-nick, a truncated cytoplasmic product of the transcription factor myc, induced fascin- 1 expression focal adhesion turnover, and change of cells' morphology, which increased their mobility and promoted cancer metastasis [102,103]. Lack of regulation via tumor suppressor p53, along the Nf-kB axis, was also implicated in overexpression of fascin-1 [104]. Namely, activation of Nf-kB signaling pathway upon deleterious p53 mutation upregulated fascin- 1 in CRC cell line; however, it was abolished when p53 was overexpressed [104]. Thus, activating p53 or suppressing the Nf- $\mathrm{kB}$ pathway can be one of the means of reducing the fascin- 1 expression and the related cancer phenotype [104]. In addition, Chen et al. remarked that mTOR stimulated fascin-1 expression levels in colon carcinoma cells HT-29 [92]. This activation was successfully reduced by using mTOR inhibitor rapamycin [92]. Moreover, by manipulating the activation status of mTOR's suppressor, AMP Kinase, the authors either increased fascin-1 expression (upon miR-451-driven degradation of AMPK) or abolished it (upon treatment of AMP Kinase activator, AICAR) [92]. Lastly, on the transcriptional level, fascin- 1 expression was also dictated by the Wnt signaling pathway, which was mediated by the transcription factor, $\beta$-catenin [30].

Long noncoding RNA, LINC00152 which acts as a competing endogenous RNA sponging with miR-632 and miR-185-3p and is under activation of Yes-associated protein 1 (Yap1) was recognized as a potent fascin-1 activator in CRC cell models and the promoter of malignant proliferation and metastasis in vivo [105]. In inflammation-associated colon cancer, fascin-1 protein levels were stabilized by the miR-146a-elicited proteasomal degradation [82]. Contrary to this, expression of miR-663, miR-145 and miR-133a was significantly abolished in CRC and inversely corelated with fascin- 1 expression pattern; all three microRNAs were not only able to decrease fascin- 1 expression, but were also able to ameliorate carcinogenesis progression [106-109]. The therapeutic potential of these miRNAs in fascin-1 suppression is yet to be investigated.

On the post-translational level, Rac was instrumental in stabilizing the interaction between fascin-1 and PKC $\gamma$ at the lamellipodia frontline of the colon cancer cells [110]. The interactions of these proteins were vital for upholding the cellular morphology with the protrusions, and their disruption ameliorated invasive carcinoma properties [110]. Moreover, Liu et al. recognized Tiam1 (T lymphoma invasion and metastasis 1) as the upstream Rac regulators, with the potential to activate fascin- 1 in CRC $[110,111]$ Thus, evaluating therapeutic potential of Rac, Taim1, and/or PKC $\gamma$ for inhibition of fascindirected reactions can be beneficial $[110,111]$.

\section{Fascin-1 and Hepatocellular Carcinoma}

\subsection{Expression Pattern of Fascin-1 in HCC and Its Potential as a Prognostic Marker}

The mRNA and protein status of fascin-1 in the resected hepatocellular carcinoma (HCC) tissues were elevated in comparison to the healthy liver samples [40-42,112]. Moreover, elevated fascin-1 expression was noted in the interdigitating dendritic cell sarcoma [113]. In HCC sections, fascin-1 was primarily expressed in the poorly differentiated parts of the specimens, and it was associated with the loss of typical trabecular HCC structures [112]. In addition, Huang and colleagues noted that in HCC collected from 77 participants, fascin-1 overexpression was positively correlated with the histological differentiation of cancer, regional invasion of lymph nodes, and distant metastasis (Table 1) [40]. Iguchi et al. made similar observations in the larger cohort and described tumors that exhibited fascin-1 upregulation as larger in size and less differentiated than the control [41]. In both studies, the survival time and the recurrence rate were significantly reduced in patients with elevated fascin- 1 levels [40,41]. Thus, they proposed that fascin-1 could serve as a promising poor prognostic factor for advanced HCC, overall survival, and regional and distant metastasis $[40,41]$. In contrast to these studies, Lin and colleagues 
showed that performing IHC with anti-fascin- 1 antibody did not exhibit significant correlations with the clinicopathological parameters of the HCC [42]. Therefore, additional studies are needed to investigate the diagnostic and prognostic potentials of fascin- 1 in HCC.

\subsection{Outcome of Fascin-1 Overexpression in HCC}

Fascin-1 overexpression was also recorded in HCC cell lines, and it played a paramount role in promoting EMT, enhancing migratory and invasive properties of the cell, as well as contributing to the multidrug resistance trait (Figure 4) $[112,114,115]$. The promotion of EMT properties was true under normoxic and hypoxic conditions, and it required interaction with the functional MMP-2 and MMP-9 [112,114]. Overexpression of fascin-1 elicited resistance to doxorubicin, which was evident in the observation that silencing fascin- 1 with RNAi technology increased cells' sensitivity to this anti-cancer drug [114].

\subsection{Fascin-1 as a Therapeutic Target in HCC}

Due to its expression pattern in HCC and the traits that it provides to the malignant cells, fascin-1 can serve as a promising therapeutic target to suppress advanced HCC and metastasis. Thus far, recombinant porcine natural killer lysin (rpNK-lysin) and doxycycline have been tested in this capacity (Table 2) [99,100]. NK-lysin is a cationic anti-microbial peptide secreted by the interleukin-2 stimulated natural killer cells and cytotoxic T lymphocytes that halters HCC cell line proliferation and reduces their invasiveness and migration [99]. These effects were possible due to rpNK-lysin-elicited downregulation of fascin- 1 in a doseand time-dependent manner [99]. The rpNK-lysin treatment further led to the disruption of the actin polymerization, the collapse of the finger-like protrusions, and the inhibition of tumor invasion and metastasis [99]. At the maximum non-toxic concentration, rpNK-lysin had a selective cytotoxic effect for the HCC cells, while affecting less than $20 \%$ of normal hepatocytes [99]. Furthermore, doxycycline successfully inhibited fascin-1 expression, and suppressed HCC proliferation and metastasis, and improved the animal survival outcomes [100]. The adverse effect associated with the doxycycline treatment for HCC and as a fascin-1 inhibitor are yet to be elucidated.

\subsection{Regulation of Fascin-1 Expression in HCC}

Although some interactive partners of fascin- 1 that influence its expression and activity in HCC are known, the complete transcriptional and post-transcriptional network has not been fully elucidated (Figure 5). One of these partners is fatty acid synthase (FASN), which co-localized with fascin-1 in HCC cell lines and whose expression pattern in HCC resembled one of fascin-1 [116]. The importance of their interaction was evident upon decreasing the FASN expression, which elicited significant downregulation of fascin-1, MMP2, MMP9, and EMT markers, and abolished EMT process, and inhibited cell migration and invasion [116]. Moreover, the vasoactive neuropeptide, urotensin II (UII), which promotes cell migration and invasion, was portrayed as a fascin-1 activator [117]. In particular, UII was shown to increase fascin- 1 expression and encourage actin polymerization and increase the JNK and NADPH Oxidase activities [117]. UII may communicate the fascin-1 activation signal via JNK and NADPH Oxidase, as the inhibition of their activities elicited decrease of fascin-1 expression [117]. Thus, investigating the inhibitors of FASN and UII to abolish the metastatic properties of HCC driven by fascin- 1 expression is promising. Moreover, miR-539, miR-145, and miR-133a were identified as tumor and fascin-1 suppressors in HCC $[118,119]$. Their expression pattern in HCC was inversely correlated [118,119]. Their upregulation resulted in abolition of fascin-1 expression, migratory and invasive traits of the cell, and the growth and proliferative capacity of HCC xenograft $[118,119]$. Thus, authors suggested that directly targeting these miRNAs would abrogate the metastatic and invasive profile of HCC elicited by fascin-1 overexpression [118,119]. 


\section{Fascin-1 and Pancreatic Cancer}

\subsection{Expression Pattern of Fascin-1 in Pancreatic Carcinomas}

The apparent differential expression of fascin- 1 between the healthy pancreatic tissue and carcinoma exemplifies this protein as a strong marker for diagnosis, prognosis, and treatment of pancreatic tumors. Fascin-1 exhibited modest basal expression levels in the healthy pancreas, with a moderate increase after the age of 60 years [43,44]. Upon the carcinogenesis initiation, the fascin- 1 expression diverged based on the type of pre-cancerous neoplasms and carcinomas. In particular, the pancreatic intraepithelial neoplasia (PanIN), which often gives rise to pancreatic adenocarcinoma (PDAC), exhibited a steady and consistent trend of fascin- 1 overexpression during the carcinogenesis progression $[43,45,46]$. The trend encompassed a slight elevation of fascin-1 expression in PanIN-1 compared to the normal pancreatic ducts and a sharp rise along with the PanIN-2 and PanIN-3 (carcinoma in situ) transitions $[43,45,46]$. The increase in fascin- 1 expression often culminated in the PDAC; the abundance of fascin-1 protein has been well recorded in the PDAC biopsy tissues obtained from patients $[44,47,120]$. Thus, fascin- 1 upregulation was marked as an early to intermediate event in PDAC neoplastic progression [46]. Fascin-1 was primarily detected in the cytoplasm of tumor, stromal, and endothelial cells, with the focal and diffuse localization to the filopodia [45].

Alterations in fascin-1 expression patterns have been implicated in less common types of pancreatic tumorigenesis. The intraductal tubulopapillary neoplasms (ITPN) exhibited negative immunopathological scores for fascin-1, mucin-2, mucin-5ac, and trypsin [121]. Furthermore, the status of fascin- 1 in the intraductal papillary mucinous neoplasms (IPMN) correlated with the increased histological grade [122]. This expression pattern contrasted with the one found in pancreatic non-ductal neoplasms, where fascin-1 was present in solid pseudopapillary tumors, pancreatoblastomas, and undifferentiated carcinomas with osteoclastic-like giant cells [123]. Furthermore, fascin-1 overexpression was recorded in the ampulla of Vader adenocarcinoma, and it was correlated with poorer differentiation, higher histological grades, and poorer overall survival [48]. In addition, the rare pancreatic extranodal follicular dendritic cell (FDC) sarcoma, composed of epithelioid and spindle cells with abundant intracytoplasmic hyaline globules, was positive for fascin-1 expression [124]. Acini cell carcinoma and the neuroendocrine tumor did not express fascin-1 [47].

\subsection{Fascin-1 as a Prognostic/Diagnostic Marker in PDAC}

The expression levels of fascin-1 in PDAC samples were positively associated with the poorly differentiated tumor (Table 1) $[44,45,125]$. Furthermore, the fascin-1 expression was observed in tumors with higher histological grades, advanced T stage, and the American Joint Committee on Cancer stage [44,47]. Moreover, PDACs that overexpressed fascin-1 demonstrated increased vascular penetration, invasion of the regional lymph nodes, as well as metastatic dissemination onto the distant secondary organs [44]. In addition, high fascin-1 expression in PDAC positively correlated with the shorter remission and survival times $[47,48]$. Based on these observations, as well as the expression trend described along the PanIN development, it has been suggested that fascin-1 can be regarded as the tumor biomarker and as a prognostic tool for advanced PDAC [43-47,120].

Studies also investigated the role of anti-fascin- 1 antibody in endoscopic ultrasoundguided fine-needle aspiration (EUS-FNA) for precise pancreatic carcinoma staging and diagnosis $[49,50]$. They found that the anti-fascin- 1 antibody exhibited high specificity but low sensitivity, which resulted in the incorrect prediction of the cancer stage and diagnosis $[49,50]$. Therefore, it was considered ineffective in cancer diagnosis, followed by the EUS-FSA [49,50]. Lastly, performing co-staining for this protein and additional markers such as actinin-4, PSCA and mucin5 gave a more accurate PDAC diagnosis (Figure 3) [46]. In addition, performing IHC to visualize extracellular matrix metalloproteinase inducer (EMMPRIN) alongside fascin-1 enhanced diagnosis precision of PDAC progression, metastasis, and overall patient survival [44]. 


\subsection{Outcome of Fascin-1 Overexpression and Suppression in PDAC}

Experiments that manipulated endogenous fascin-1 levels in the in vitro and in vivo models of pancreatic carcinoma unveiled that fascin- 1 expression and activity represent vital determinants of tumor aggressiveness and its ability to colonize secondary sites (Figure 4). Overexpression of fascin- 1 in the pancreatic carcinoma cell line, MIA-PaCa2 , elicited apparent actin remodeling in the cytoplasm, followed by the change in cell morphology portrayed by the prominent finger-like protrusions $[47,126]$. These cells also gained motility abilities, which was evident in the prominent cell migration as well as in the disruption of the cell-to-cell adhesion and cell aggregation $[47,126]$. Perhaps the mechanistic rationale behind this phenomenon was the upregulation of the MMP-2 upon fascin-1 overexpression along with the Protein Kinase C (PKC)/ERK pathways axis [47]. Moreover, xenograft studies using this cell line showed that although the overexpression of fascin- 1 augmented tumor invasion to the skin, it did not change the proliferative capacity of pancreatic carcinoma when compared to the control [126]. PDAC cells that overexpressed fascin-1 exhibited the multidrug resistance phenotype towards drugs such as docetaxel and TS-1, which is a combination of 5-fluorouracil and tegafur (a metabolically activated 5-fluorouracil prodrug) $[127,128]$. Upon silencing of fascin-1, however, the pancreatic carcinoma cells exhibited lower migration and invasion rates [45]. Lack of these abilities carried in the mouse model of pancreatic ductal adenocarcinoma, KPC (K-Ras ${ }^{\text {LL.G12D/+ }}$, $\operatorname{Trp} 53^{\mathrm{R} 172 \mathrm{H} /+}$, Pdx-1-Cre) mouse, which upon the disruption of fascin-1 gene, exhibited less tumor burden, longer survival time, and the later onset of the tumor formation [45].

\subsection{Fascin-1 as a Therapeutic Target in PDAC}

The valuable role of fascin-1 in the PDAC progression, invasion, and metastasis places it in the group of effective therapeutic targets for PDAC treatment. The antibiotic and an ionophore, salinomycin, was identified as one of the therapeutics that effectively inhibited fascin-1 and suppressed PDAC progression (Table 2) [101]. They discovered that salinomycin treatment of PDAC cell line successfully relocated fascin- 1 from the filopodia [101]. This elicited the disruption of actin remodeling, the creation of the circular dorsal ruffle formation, and the inhibition of cancer metastasis to the secondary sites [101]. Salinomycin treatment was well tolerated by the animals during the course of treatment [101].

\subsection{Regulation of Fascin-1 in PDAC}

Notch-4 signaling pathway coupled to the Akt signaling was identified as the fascin-1 activator in the PDAC (Figure 5) [128]. Furthermore, the epithelial-to-mesenchymal transition transcription factor, Slug, was noted as a prominent fascin- 1 transcriptional activator in the pancreatic carcinoma [45]. Lastly, the PDAC invasion and metastasis was dictated by the hypoxic microenvironment, via hypoxia inducible factor $1 \alpha$ (HIF-1 $\alpha)$ elicited upregulation of fascin-1 [47]. On the contrary, fascin-1 expression was downregulated by miR-133a [129]. Thus, inhibitors of Slug, HIF-1 $\alpha$, Notch4, and Akt signaling pathways, and activators of miR-133a, in theory, could be utilized to abrogate fascin-1 expression in PDACs and to ameliorate invasiveness and metastatic abilities of pancreatic carcinogenesis.

\section{Conclusions}

Fascin-1, a monomeric actin-binding protein, is responsible for bundling and crosslinking actin filaments at the cell's leading edge. It promotes the formation of pseudopodia that mediate cellular movement, which is crucial for metastatic dissemination of the primary tumor. Although the basal expression of fascin-1 in the GI tract is minimal, it increases GI tract carcinogenesis progression. High fascin-1 expression is associated with dismal GI tract cancer clinicopathological outcomes, as it is correlated with decreased patient survival time, histological stages of cancers, and regional and distant metastases (Figure 6). Therefore, fascin- 1 has been portrayed as a promising diagnostic marker that would provide a more precise histopathological stage of cancer and an unfavorable prognostic tool for advanced GI tract carcinogenesis, overall survival, and metastasis. The significance 
of its involvement as an oncogene is evident from the in vivo and in vitro experimental findings that its loss-of-function is sufficient to abrogate proliferation, migration, and invasive properties of GI tract cancers. Therefore, suppressing its expression and activity by pharmacological agents has been examined as an adjuvant therapeutic strategy for this type of carcinogenesis. This can be done by targeting fascin- 1 directly, or indirectly by modulating its activators and suppressors via pharmacological means.

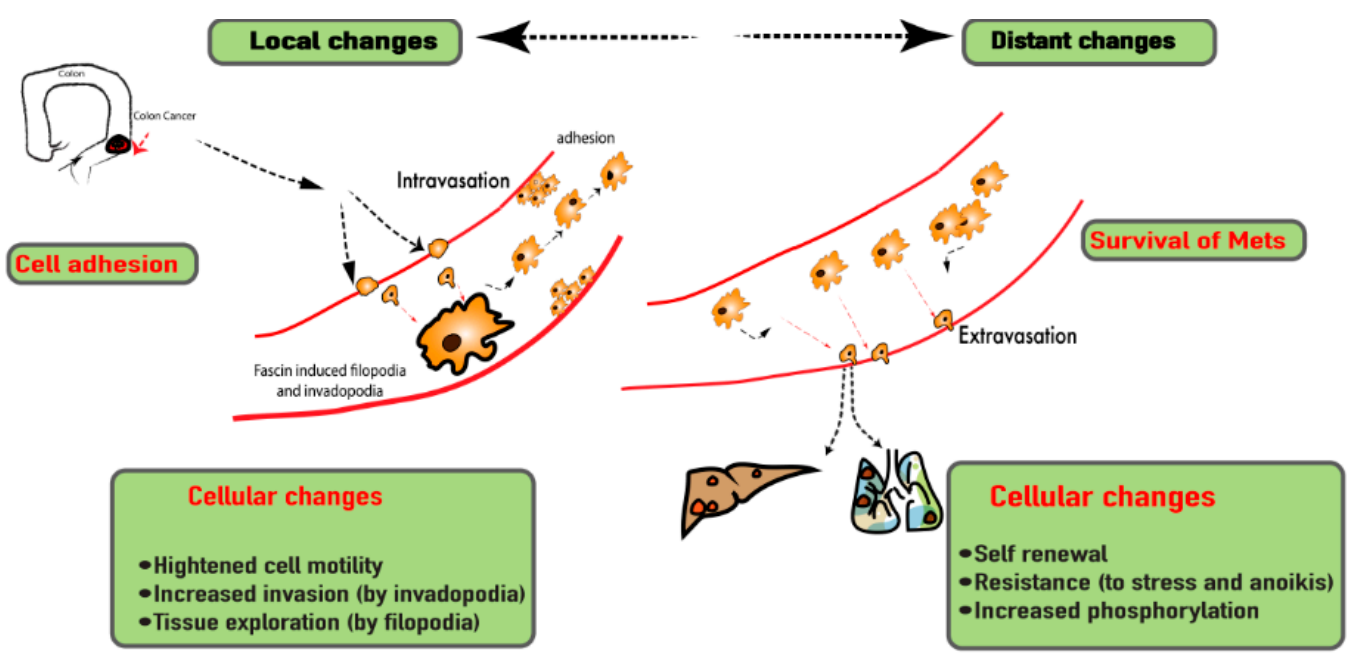

Figure 6. Mechanism and role of fascin-1 in the tumor progression.

Author Contributions: Conception and design: H.G., J.K., and B.R.; literature search: H.G., J.K., and A.P.; first draft: B.R.; critical revision and editing: S.A.A.S., S.G., S.S., P.B., A.A., A.P.; final approval: B.R., J.K., H.G., S.A.A.S., S.G., S.S., P.B., A.A., A.P.; all authors. All authors have read and agreed to the published version of the manuscript.

Funding: This research received no external funding.

Conflicts of Interest: The authors declare no conflict of interest.

$\begin{array}{ll}\text { Abbreviation } & \\ \text { ABD } & \text { actin-binding domain } \\ \text { BMI1 } & \text { BMI1 proto-oncogene, polycomb ring finger } \\ \text { CTGF } & \text { Connective tissue growth factor } \\ \text { CRC } & \text { colorectal carcinoma } \\ \text { CYR61 } & \text { Cysteine-rich, angiogenic inducer 61 } \\ \text { EBV } & \text { Epstein-Barr virus } \\ \text { EGFR } & \text { epidermal growth factor receptor } \\ \text { EMMPRIN } & \text { extracellular matrix metalloproteinase inducer } \\ \text { EMT } & \text { epithelial-to-mesenchymal transition } \\ \text { ESCC } & \text { esophageal squamous cell carcinoma } \\ \text { EUS-FNA } & \text { endoscopic ultrasound-guided fine-needle aspiration } \\ \text { FASN } & \text { fatty acid synthase } \\ \text { GC } & \text { gastric carcinoma } \\ \text { GI tract } & \text { gastrointestinal tract } \\ \text { HCC } & \text { hepatocellular carcinoma } \\ \text { HIF-1 } \alpha & \text { hypoxia inducible factor 1 } \\ \text { IHC } & \text { immunohistochemistry } \\ \text { IPMN } & \text { intraductal papillary mucinous neoplasms } \\ \text { ITPN } & \text { intraductal tubulopapillary neoplasms } \\ \text { MMP-2 } & \text { matrix metalloproteinase-2 } \\ \text { MMP-9 } & \text { matrix metalloproteinase-9 } \\ \text { PanIN } & \text { pancreatic intraepithelial neoplasia } \\ & \end{array}$




$\begin{array}{ll}\text { PDAC } & \text { pancreatic adenoracinoma } \\ \text { PKC } & \text { Protein Kinase C } \\ \text { rpNK-lysin } & \text { recombinant porcine natural killer lysin } \\ \text { TGF- } \beta & \text { transforming growth factor } \\ \text { Sp1 } & \text { specificity protein 1 } \\ \text { STAT3 } & \text { signal transducer and activator of transcription } \\ \text { Tiam1 } & \text { T lymphoma invasion and metastasis 1 } \\ \text { UII } & \text { urotensin II } \\ \text { ZNF139 } & \text { zinc finger protein 139 }\end{array}$

\section{References}

1. Siegel, R.L.; Miller, K.D.; Fuchs, H.E.; Jemal, A. Cancer Statistics, 2021. CA Cancer J. Clin. 2021, 71, 7-33. [CrossRef]

2. Siegel, R.L.; Miller, K.D.; Jemal, A. Cancer statistics, 2020. CA Cancer J. Clin. 2020, 70, 7-30. [CrossRef]

3. Riihimäki, M.; Hemminki, A.; Sundquist, J.; Hemminki, K. Patterns of metastasis in colon and rectal cancer. Sci Rep. 2016, 6, 29765. [CrossRef] [PubMed]

4. Riihimäki, M.; Hemminki, A.; Sundquist, K.; Sundquist, J.; Hemminki, K. Metastatic spread in patients with gastric cancer. Oncotarget 2016, 7, 52307-52316. [CrossRef] [PubMed]

5. $\quad$ Fares, J.; Fares, M.Y.; Khachfe, H.H.; Salhab, H.A.; Fares, Y. Molecular principles of metastasis: A hallmark of cancer revisited. Signal. Transduct. Target. Ther. 2020, 5, 28. [CrossRef]

6. Svitkina, T. The Actin Cytoskeleton and Actin-Based Motility. Cold Spring Harb. Perspect. Biol. 2018, 10, a018267. [CrossRef]

7. Innocenti, M. New insights into the formation and the function of lamellipodia and ruffles in mesenchymal cell migration. Cell Adh. Migr. 2018, 12, 401-416. [CrossRef] [PubMed]

8. Izdebska, M.; Zielińska, W.; Grzanka, D.; Gagat, M. The Role of Actin Dynamics and Actin-Binding Proteins Expression in Epithelial-to-Mesenchymal Transition and Its Association with Cancer Progression and Evaluation of Possible Therapeutic Targets. Biomed. Res. Int. 2018, 2018, 4578373. [CrossRef]

9. Jayo, A.; Parsons, M. Fascin: A key regulator of cytoskeletal dynamics. Int. J. Biochem. Cell Biol. 2010, 42, 1614-1617. [CrossRef] [PubMed]

10. Kureishy, N.; Sapountzi, V.; Prag, S.; Anilkumar, N.; Adams, J.C. Fascins, and their roles in cell structure and function. Bioessays 2002, 24, 350-361. [CrossRef] [PubMed]

11. Sedeh, R.S.; Fedorov, A.A.; Fedorov, E.V.; Ono, S.; Matsumura, F.; Almo, S.C.; Bathe, M. Structure, evolutionary conservation, and conformational dynamics of Homo sapiens fascin-1, an F-actin crosslinking protein. J. Mol. Biol. 2010, 400, 589-604. [CrossRef]

12. Jayo, A.; Malboubi, M.; Antoku, S.; Chang, W.; Ortiz-Zapater, E.; Groen, C.; Pfisterer, K.; Tootle, T.; Charras, G.; Gundersen, G.G.; et al. Fascin Regulates Nuclear Movement and Deformation in Migrating Cells. Dev. Cell 2016, 38, 371-383. [CrossRef]

13. Lin, S.; Huang, C.; Gunda, V.; Sun, J.; Chellappan, S.P.; Li, Z.; Izumi, V.; Fang, B.; Koomen, J.; Singh, P.K.; et al. Fascin Controls Metastatic Colonization and Mitochondrial Oxidative Phosphorylation by Remodeling Mitochondrial Actin Filaments. Cell Rep. 2019, 28, 2824-2836.e8. [CrossRef] [PubMed]

14. Ai, D.; Zhu, H.; Ren, W.; Chen, Y.; Liu, Q.; Deng, J.; Ye, J.; Fan, J.; Zhao, K. Patterns of distant organ metastases in esophageal cancer: A population-based study. J. Thorac. Dis. 2017, 9, 3023-3030. [CrossRef]

15. Hu, N.; Qian, L.; Hu, Y.; Shou, J.-Z.; Wang, C.; Giffen, C.; Wang, Q.-H.; Wang, Y.; Goldstein, A.M.; Emmert-Buck, M.; et al. Quantitative real-time RT-PCR validation of differential mRNA expression of SPARC, FADD, Fascin, COL7A1, CK4, TGM3, ECM1, PPL and EVPLin esophageal squamous cell carcinoma. BMC Cancer 2006, 6, 33. [CrossRef]

16. Shen, T.Y.; Mei, L.L.; Qiu, Y.T.; Shi, Z.Z. Identification of candidate target genes of genomic aberrations in esophageal squamous cell carcinoma. Oncol. Lett. 2016, 12, 2956-2961. [CrossRef] [PubMed]

17. Takikita, M.; Hu, N.; Shou, J.Z.; Giffen, C.; Wang, Q.H.; Wang, C.; Hewitt, S.M.; Taylor, P.R. Fascin and CK4 as biomarkers for esophageal squamous cell carcinoma. Anticancer Res. 2011, 31, 945-952.

18. Zhang, H.; Xu, L.; Xiao, D.; Xie, J.; Zeng, H.; Cai, W.; Niu, Y.; Yang, Z.; Shen, Z.; Li, E. Fascin is a potential biomarker for early-stage oesophageal squamous cell carcinoma. J. Clin. Pathol. 2006, 59, 958-964. [CrossRef]

19. Hashimoto, Y.; Ito, T.; Inoue, H.; Okumura, T.; Tanaka, E.; Tsunoda, S.; Higashiyama, M.; Watanabe, G.; Imamura, M.; Shimada, Y. Prognostic significance of fascin overexpression in human esophageal squamous cell carcinoma. Clin. Cancer Res. 2005, 11, 2597-2605. [CrossRef]

20. Hsu, K.F.; Lin, C.K.; Yu, C.P.; Tzao, C.; Lee, S.C.; Lee, Y.Y.; Tsai, W.C.; Jin, J.S. Cortactin, fascin, and survivin expression associated with clinicopathological parameters in esophageal squamous cell carcinoma. Dis. Esophagus 2009, 22, 402-408. [CrossRef]

21. Cao, H.H.; Zheng, C.P.; Wang, S.H.; Wu, J.Y.; Shen, J.H.; Xu, X.E.; Fu, J.H.; Wu, Z.Y.; Li, E.M.; Xu, L.Y. A molecular prognostic model predicts esophageal squamous cell carcinoma prognosis. PLoS ONE 2014, 9, e106007. [CrossRef] [PubMed]

22. Wang, G.; Gu, Y.; Lu, W.; Liu, X.; Fu, H. Fascin1 promotes gastric cancer progression by facilitatingcell migrationand epithelialmesenchymal transition. Pathol. Res. Pract. 2018, 214, 1362-1369. [CrossRef] [PubMed]

23. Li, X.; Zheng, H.; Hara, T.; Takahashi, H.; Masuda, S.; Wang, Z.; Yang, X.; Guan, Y.; Takano, Y. Aberrant expression of cortactin and fascin are effective markers for pathogenesis, invasion, metastasis and prognosis of gastric carcinomas. Int. J. Oncol. 2008, 33, 69-79. [CrossRef] [PubMed] 
24. Hashimoto, Y.; Shimada, Y.; Kawamura, J.; Yamasaki, S.; Imamura, M. The prognostic relevance of fascin expression in human gastric carcinoma. Oncology 2004, 67, 262-270. [CrossRef]

25. Tsai, W.C.; Jin, J.S.; Chang, W.K.; Chan, D.C.; Yeh, M.K.; Cherng, S.C.; Lin, L.F.; Sheu, L.F.; Chao, Y.C. Association of cortactin and fascin-1 expression in gastric adenocarcinoma: Correlation with clinicopathological parameters. J. Histochem. Cytochem. 2007, 55, 955-962. [CrossRef] [PubMed]

26. Tu, L.; Xu, J.; Wang, M.; Zhao, W.Y.; Zhang, Z.Z.; Zhu, C.C.; Tang, D.F.; Zhang, Y.Q.; Wang, D.H.; Zuo, J.; et al. Correlations of fascin-1 and cadherin-17 protein expression with clinicopathologic features and prognosis of patients with gastric cancer. Tumour Biol. 2016, 37, 8775-8782. [CrossRef] [PubMed]

27. Kim, S.J.; Kim, D.C.; Kim, M.C.; Jung, G.J.; Kim, K.H.; Jang, J.S.; Kwon, H.C.; Kim, Y.M.; Jeong, J.S. Fascin expression is related to poor survival in gastric cancer. Pathol. Int. 2012, 62, 777-784. [CrossRef]

28. Puppa, G.; Maisonneuve, P.; Sonzogni, A.; Masullo, M.; Chiappa, A.; Valerio, M.; Zampino, M.G.; Franceschetti, I.; Capelli, P.; Chilosi, M.; et al. Independent prognostic value of fascin immunoreactivity in stage III-IV colonic adenocarcinoma. Br. J. Cancer 2007, 96, 1118-1126. [CrossRef]

29. Qualtrough, D.; Singh, K.; Banu, N.; Paraskeva, C.; Pignatelli, M. The actin-bundling protein fascin is overexpressed in colorectal adenomas and promotes motility in adenoma cells in vitro. Br. J. Cancer 2009, 101, 1124-1129. [CrossRef]

30. Vignjevic, D.; Schoumacher, M.; Gavert, N.; Janssen, K.P.; Jih, G.; Laé, M.; Louvard, D.; Ben-Ze'ev, A.; Robine, S. Fascin, a novel target of beta-catenin-TCF signaling, is expressed at the invasive front of human colon cancer. Cancer Res. 2007, 67, 6844-6853. [CrossRef]

31. Hashimoto, Y.; Skacel, M.; Lavery, I.C.; Mukherjee, A.L.; Casey, G.; Adams, J.C. Prognostic significance of fascin expression in advanced colorectal cancer: An immunohistochemical study of colorectal adenomas and adenocarcinomas. BMC Cancer 2006, 6, 241. [CrossRef]

32. Jung, E.J.; Lee, J.H.; Min, B.W.; Kim, Y.S.; Choi, J.S. Clinicopathologic significance of fascin, extracellular matrix metalloproteinase inducer, and ezrin expressions in colorectal adenocarcinoma. Indian J. Pathol. Microbiol. 2011, 54, 32-36. [CrossRef]

33. Tsai, W.C.; Chao, Y.C.; Sheu, L.F.; Chang, J.L.; Nieh, S.; Jin, J.S. Overexpression of fascin-1 in advanced colorectal adenocarcinoma: Tissue microarray analysis of immunostaining scores with clinicopathological parameters. Dis. Markers 2007, 23, 153-160. [CrossRef] [PubMed]

34. Ozerhan, I.H.; Ersoz, N.; Onguru, O.; Ozturk, M.; Kurt, B.; Cetiner, S. Fascin expression in colorectal carcinomas. Clinics (São Paulo) 2010, 65, 157-164. [CrossRef] [PubMed]

35. Piskor, B.M.; Pryczynicz, A.; Lubowicka, E.; Miniewska, K.; Zinczuk, J.; Zareba, K.; Guzinska-Ustymowicz, K. Immunohistochemical expression of Fascin-1 in colorectal cancer in relation to clinical and pathological parameters. Folia Histochem. Cytobiol. 2018, 56, 106-112. [CrossRef]

36. Roseweir, A.K.; Kong, C.Y.; Park, J.H.; Bennett, L.; Powell, A.; Quinn, J.; van Wyk, H.C.; Horgan, P.G.; McMillan, D.C.; Edwards, J.; et al. A novel tumor-based epithelial-to-mesenchymal transition score that associates with prognosis and metastasis in patients with Stage II/III colorectal cancer. Int. J. Cancer 2019, 144, 150-159. [CrossRef]

37. Tampakis, A.; Tampaki, E.C.; Nonni, A.; Kostakis, I.D.; Posabella, A.; Kontzoglou, K.; von Flüe, M.; Felekouras, E.; Kouraklis, G.; Nikiteas, N. High fascin-1 expression in colorectal cancer identifies patients at high risk for early disease recurrence and associated mortality. BMC Cancer 2021, 21, 153. [CrossRef]

38. Oh, S.Y.; Kim, Y.B.; Suh, K.W.; Paek, O.J.; Moon, H.Y. Prognostic impact of fascin-1 expression is more significant in advanced colorectal cancer. J. Surg. Res. 2012, 172, 102-108. [CrossRef]

39. Koçer, N.E.; Kayaselçuk, F. Is availability of anti-EGFR therapy for the colorectal adenocarcinomas showing fascin expression limited? Target. Oncol. 2014, 9, 171-175. [CrossRef]

40. Huang, X.; Ji, J.; Xue, H.; Zhang, F.; Han, X.; Cai, Y.; Zhang, J.; Ji, G. Fascin and cortactin expression is correlated with a poor prognosis in hepatocellular carcinoma. Eur. J. Gastroenterol. Hepatol. 2012, 24, 633-639. [CrossRef]

41. Iguchi, T.; Aishima, S.; Umeda, K.; Sanefuji, K.; Fujita, N.; Sugimachi, K.; Gion, T.; Taketomi, A.; Maehara, Y.; Tsuneyoshi, M. Fascin expression in progression and prognosis of hepatocellular carcinoma. J. Surg. Oncol. 2009, 100, 575-579. [CrossRef]

42. Lin, C.K.; Jin, J.S.; Yu, C.P.; Tsai, W.C. Expression of LGR8 and related biomarkers in hepatocellular carcinoma: Correlation with clinicopathological parameters. Chin. J. Physiol. 2011, 54, 161-168. [CrossRef] [PubMed]

43. Misiura, M.; Zińczuk, J.; Zaręba, K.; Kamińska, D.; Guzińska-Ustymowicz, K.; Pryczynicz, A. Actin-Bundling Proteins (Actinin-4 and Fascin-1) are Involved in the Development of Pancreatic Intraepithelial Neoplasia (PanIN). Am. J. Med. Sci. 2020, 359, 147-155. [CrossRef]

44. Tsai, W.C.; Chao, Y.C.; Sheu, L.F.; Lin, Y.F.; Nieh, S.; Chen, A.; Yu, C.P.; Jin, J.S. EMMPRIN and fascin overexpression associated with clinicopathologic parameters of pancreatobiliary adenocarcinoma in Chinese people. Apmis 2007, 115, 929-938. [CrossRef]

45. Li, A.; Morton, J.P.; Ma, Y.; Karim, S.A.; Zhou, Y.; Faller, W.J.; Woodham, E.F.; Morris, H.T.; Stevenson, R.P.; Juin, A.; et al. Fascin is regulated by slug, promotes progression of pancreatic cancer in mice, and is associated with patient outcomes. Gastroenterology 2014, 146, 1386-1396.e17. [CrossRef]

46. Maitra, A.; Adsay, N.V.; Argani, P.; Iacobuzio-Donahue, C.; De Marzo, A.; Cameron, J.L.; Yeo, C.J.; Hruban, R.H. Multicomponent analysis of the pancreatic adenocarcinoma progression model using a pancreatic intraepithelial neoplasia tissue microarray. Mod. Pathol. 2003, 16, 902-912. [CrossRef] 
47. Zhao, X.; Gao, S.; Ren, H.; Sun, W.; Zhang, H.; Sun, J.; Yang, S.; Hao, J. Hypoxia-inducible factor-1 promotes pancreatic ductal adenocarcinoma invasion and metastasis by activating transcription of the actin-bundling protein fascin. Cancer Res. 2014, 74, 2455-2464. [CrossRef]

48. Tsai, W.C.; Lin, C.K.; Lee, H.S.; Gao, H.W.; Nieh, S.; Chan, D.C.; Jin, J.S. The correlation of cortactin and fascin-1 expression with clinicopathological parameters in pancreatic and ampulla of Vater adenocarcinoma. Apmis 2013, 121, 171-181. [CrossRef] [PubMed]

49. Agarwal, B.; Ludwig, O.J.; Collins, B.T.; Cortese, C. Immunostaining as an adjunct to cytology for diagnosis of pancreatic adenocarcinoma. Clin. Gastroenterol. Hepatol. 2008, 6, 1425-1431. [CrossRef] [PubMed]

50. Dim, D.C.; Jiang, F.; Qiu, Q.; Li, T.; Darwin, P.; Rodgers, W.H.; Peng, H.Q. The usefulness of S100P, mesothelin, fascin, prostate stem cell antigen, and 14-3-3 sigma in diagnosing pancreatic adenocarcinoma in cytological specimens obtained by endoscopic ultrasound guided fine-needle aspiration. Diagn. Cytopathol. 2014, 42, 193-199. [CrossRef]

51. Tan, H.; Zhang, H.; Xie, J.; Chen, B.; Wen, C.; Guo, X.; Zhao, Q.; Wu, Z.; Shen, J.; Wu, J.; et al. A novel staging model to classify oesophageal squamous cell carcinoma patients in China. Br. J. Cancer 2014, 110, 2109-2115. [CrossRef]

52. Wang, C.; Wang, J.; Chen, Z.; Gao, Y.; He, J. Immunohistochemical prognostic markers of esophageal squamous cell carcinoma: A systematic review. Chin. J. Cancer 2017, 36, 65. [CrossRef]

53. Perisetti, A.; Bellamkonda, M.; Konda, M.; Edwards, S.; Ali Khan, S.; Bansal, P.; Hu, Z.D.; Goyal, H. Tumor-associated antigens and their antibodies in the screening, diagnosis, and monitoring of esophageal cancers. Eur. J. Gastroenterol. Hepatol. 2020, 32, 779-788. [CrossRef]

54. Chen, W.X.; Hong, X.B.; Hong, C.Q.; Liu, M.; Li, L.; Huang, L.S.; Xu, L.Y.; Xu, Y.W.; Peng, Y.H.; Li, E.M. Tumor-associated autoantibodies against Fascin as a novel diagnostic biomarker for esophageal squamous cell carcinoma. Clin. Res. Hepatol. Gastroenterol. 2017, 41, 327-332. [CrossRef] [PubMed]

55. Du, Z.P.; Wu, B.L.; Xie, J.J.; Lin, X.H.; Qiu, X.Y.; Zhan, X.F.; Wang, S.H.; Shen, J.H.; Li, E.M.; Xu, L.Y. Network Analyses of Gene Expression following Fascin Knockdown in Esophageal Squamous Cell Carcinoma Cells. Asian Pac. J. Cancer Prev. 2015, 16, 5445-5451. [CrossRef] [PubMed]

56. Xie, J.J.; Xu, L.Y.; Zhang, H.H.; Cai, W.J.; Mai, R.Q.; Xie, Y.M.; Yang, Z.M.; Niu, Y.D.; Shen, Z.Y.; Li, E.M. Role of fascin in the proliferation and invasiveness of esophageal carcinoma cells. Biochem. Biophys. Res. Commun. 2005, 337, 355-362. [CrossRef]

57. Xie, J.J.; Xu, L.Y.; Wu, J.Y.; Shen, Z.Y.; Zhao, Q.; Du, Z.P.; Lv, Z.; Gu, W.; Pan, F.; Xu, X.E.; et al. Involvement of CYR61 and CTGF in the fascin-mediated proliferation and invasiveness of esophageal squamous cell carcinomas cells. Am. J. Pathol. 2010, 176, 939-951. [CrossRef]

58. Ortiz, C.M.; Ito, T.; Hashimoto, Y.; Nagayama, S.; Iwai, A.; Tsunoda, S.; Sato, F.; Martorell, M.; Garcia, J.A.; Perez, A.; et al. Effects of small interfering RNAs targeting fascin on human esophageal squamous cell carcinoma cell lines. Diagn. Pathol. $2010,5,41$. [CrossRef]

59. Hou, J.; Guo, Z.Y.; Xie, J.J.; Li, E.M.; Xu, L.Y. Fascin overexpression is regulated by the transactivation of the promoter but not by its hypomethylation in esophageal squamous cell carcinoma. Mol. Med. Rep. 2009, 2, 843-849. [CrossRef]

60. Lu, X.F.; Li, E.M.; Du, Z.P.; Xie, J.J.; Guo, Z.Y.; Gao, S.Y.; Liao, L.D.; Shen, Z.Y.; Xie, D.; Xu, L.Y. Specificity protein 1 regulates fascin expression in esophageal squamous cell carcinoma as the result of the epidermal growth factor/extracellular signal-regulated kinase signaling pathway activation. Cell. Mol. Life Sci. 2010, 67, 3313-3329. [CrossRef]

61. Kano, M.; Seki, N.; Kikkawa, N.; Fujimura, L.; Hoshino, I.; Akutsu, Y.; Chiyomaru, T.; Enokida, H.; Nakagawa, M.; Matsubara, H. miR-145, miR-133a and miR-133b: Tumor-suppressive miRNAs target FSCN1 in esophageal squamous cell carcinoma. Int. J. Cancer 2010, 127, 2804-2814. [CrossRef]

62. Akanuma, N.; Hoshino, I.; Akutsu, Y.; Murakami, K.; Isozaki, Y.; Maruyama, T.; Yusup, G.; Qin, W.; Toyozumi, T.; Takahashi, M.; et al. MicroRNA-133a regulates the mRNAs of two invadopodia-related proteins, FSCN1 and MMP14, in esophageal cancer. Br. J. Cancer 2014, 110, 189-198. [CrossRef]

63. Liu, R.; Liao, J.; Yang, M.; Sheng, J.; Yang, H.; Wang, Y.; Pan, E.; Guo, W.; Pu, Y.; Kim, S.J.; et al. The cluster of miR-143 and miR-145 affects the risk for esophageal squamous cell carcinoma through co-regulating fascin homolog 1. PLoS ONE 2012, 7, e33987. [CrossRef] [PubMed]

64. Shen, S.N.; Li, K.; Liu, Y.; Yang, C.L.; He, C.Y.; Wang, H.R. Down-regulation of long noncoding RNA PVT1 inhibits esophageal carcinoma cell migration and invasion and promotes cell apoptosis via microRNA-145-mediated inhibition of FSCN1. Mol. Oncol. 2019, 13, 2554-2573. [CrossRef]

65. Lin, C.; Zhang, S.; Wang, Y.; Wang, Y.; Nice, E.; Guo, C.; Zhang, E.; Yu, L.; Li, M.; Liu, C.; et al. Functional Role of a Novel Long Noncoding RNA TTN-AS1 in Esophageal Squamous Cell Carcinoma Progression and Metastasis. Clin. Cancer Res. 2018, 24, 486-498. [CrossRef] [PubMed]

66. Zeng, F.-M.; Wang, X.-N.; Shi, H.-S.; Xie, J.-J.; Du, Z.-P.; Liao, L.-D.; Nie, P.-J.; Xu, L.-Y.; Li, E.-M. Fascin phosphorylation sites combine to regulate esophageal squamous cancer cell behavior. Amino Acids 2017, 49, 943-955. [CrossRef]

67. Zhao, Q.; Shen, J.H.; Shen, Z.Y.; Wu, Z.Y.; Xu, X.E.; Xie, J.J.; Wu, J.Y.; Huang, Q.; Lu, X.F.; Li, E.M.; et al. Phosphorylation of fascin decreases the risk of poor survival in patients with esophageal squamous cell carcinoma. J. Histochem. Cytochem. 2010, 58, 979-988. [CrossRef]

68. Zheng, H.C.; Zhao, S. The meta and bioinformatics analysis of fascin expression in gastric cancer: A potential marker for aggressiveness and worse prognosis. Oncotarget 2017, 8, 105574-105583. [CrossRef] 
69. Son, B.K.; Kim, D.H.; Min, K.W.; Kim, E.K.; Kwon, M.J. Smad4/Fascin index is highly prognostic in patients with diffuse type EBV-associated gastric cancer. Pathol. Res. Pract. 2018, 214, 475-481. [CrossRef]

70. Hao, Y.J.; Li, Y.; Fan, L.Q.; Zhao, Q.; Tan, B.B.; Jiao, Z.K.; Zhao, X.F.; Zhang, Z.D.; Wang, D. Role of RNA-interference-induced zinc finger protein 139 suppression in gastric cancer cell sensitivity to chemotherapeutic agents. Oncol. Lett. 2015, 10, 1333-1338. [CrossRef]

71. Kim, S.J.; Choi, I.J.; Cheong, T.C.; Lee, S.J.; Lotan, R.; Park, S.H.; Chun, K.H. Galectin-3 increases gastric cancer cell motility by up-regulating fascin-1 expression. Gastroenterology 2010, 138, 1035-1045.e2. [CrossRef]

72. Li, L.; Cao, F.; Liu, B.; Luo, X.; Ma, X.; Hu, Z. TGF- $\beta$ induces fascin expression in gastric cancer via phosphorylation of smad3 linker area. Am. J. Cancer Res. 2015, 5, 1890-1896. [PubMed]

73. Fu, H.; Hu, Z.; Wen, J.; Wang, K.; Liu, Y. TGF-beta promotes invasion and metastasis of gastric cancer cells by increasing fascin1 expression via ERK and JNK signal pathways. Acta Biochim. Biophys. Sin. 2009, 41, 648-656. [CrossRef] [PubMed]

74. Yao, J.; Qian, C.J.; Ye, B.; Zhao, Z.Q.; Wei, J.; Liang, Y.; Zhang, X. Signal transducer and activator of transcription 3 signaling upregulates fascin via nuclear factor- $\mathrm{kB}$ in gastric cancer: Implications in cell invasion and migration. Oncol. Lett. 2014, 7, 902-908. [CrossRef]

75. Yang, Y.; Zhao, Q.; Cai, Z.; Cheng, G.; Chen, M.; Wang, J.; Zhong, H. Fas Signaling Promotes Gastric Cancer Metastasis through STAT3-Dependent Upregulation of Fascin. PLOS ONE 2015, 10, e0125132. [CrossRef] [PubMed]

76. Guo, L.; Bai, H.; Zou, D.; Hong, T.; Liu, J.; Huang, J.; He, P.; Zhou, Q.; He, J. The role of microRNA-133b and its target gene FSCN1 in gastric cancer. J. Exp. Clin. Cancer Res. 2014, 33, 99. [CrossRef]

77. Lai, C.; Chen, Z.; Li, R. MicroRNA-133a inhibits proliferation and invasion, and induces apoptosis in gastric carcinoma cells via targeting fascin actin-bundling protein 1. Mol. Med. Rep. 2015, 12, 1473-1478. [CrossRef]

78. Xue, M.; Zhao, L.; Yang, F.; Li, Z.; Li, G. MicroRNA-145 inhibits the malignant phenotypes of gastric carcinoma cells via downregulation of fascin 1 expression. Mol. Med. Rep. 2016, 13, 1033-1039. [CrossRef]

79. Zhang, M.; Dong, B.B.; Lu, M.; Zheng, M.J.; Chen, H.; Ding, J.Z.; Xu, A.M.; Xu, Y.H. miR-429 functions as a tumor suppressor by targeting FSCN1 in gastric cancer cells. OncoTargets Ther. 2016, 9, 1123-1133. [CrossRef]

80. Li, Y.; Gao, Y.; Xu, Y.; Ma, H.; Yang, M. Down-regulation of miR-326 is associated with poor prognosis and promotes growth and metastasis by targeting FSCN1 in gastric cancer. Growth Factors 2015, 33, 267-274. [CrossRef]

81. Wang, C.Q.; Wang, Y.; Huang, B.F.; Tang, C.H.; Du, Z.; Zeng, Y.; Wang, Q.; Shao, J.K.; Jin, L.L. High Expression of Both Resistin and Fascin-1 Predicts a Poor Prognosis in Patients with Colorectal Cancer. Biomed. Res. Int. 2020, 2020, 8753175. [CrossRef]

82. Kanda, Y.; Kawaguchi, T.; Osaki, M.; Onuma, K.; Ochiya, T.; Kitagawa, T.; Okada, F. Fascin protein stabilization by miR-146a implicated in the process of a chronic inflammation-related colon carcinogenesis model. Inflamm. Res. 2018, 67, 839-846. [CrossRef] [PubMed]

83. Al-Antary, N.; Farghaly, H.; Aboulkassim, T.; Yasmeen, A.; Akil, N.; Al Moustafa, A.E. Epstein-Barr virus and its association with Fascin expression in colorectal cancers in the Syrian population: A tissue microarray study. Hum. Vaccines Immunother. 2017, 13, 1573-1578. [CrossRef] [PubMed]

84. Ghabreau, L.; Segal, E.; Yasmeen, A.; Kassab, A.; Akil, N.; Al Moustafa, A.-E. High-risk human papillomavirus infections in colorectal cancer in the Syrian population and their association with Fascin, Id-1 and P-cadherin expressions: A tissue microarray study. Clin. Cancer Investig. J. 2012, 1, 26-30. [CrossRef]

85. Shi, S.; Zheng, H.C.; Zhang, Z.G. Roles of Fascin mRNA expression in colorectal cancer: Meta-analysis and bioinformatics analysis. Mol. Clin. Oncol. 2020, 13, 119-128. [CrossRef]

86. Tan, V.Y.; Lewis, S.J.; Adams, J.C.; Martin, R.M. Association of fascin-1 with mortality, disease progression and metastasis in carcinomas: A systematic review and meta-analysis. BMC Med. 2013, 11, 52. [CrossRef] [PubMed]

87. Alajez, N.M. Significance of BMI1 and FSCN1 expression in colorectal cancer. Saudi J. Gastroenterol. 2016, 22, 288-293. [CrossRef]

88. Schoumacher, M.; El-Marjou, F.; Laé, M.; Kambou, N.; Louvard, D.; Robine, S.; Vignjevic, D.M. Conditional expression of fascin increases tumor progression in a mouse model of intestinal cancer. Eur. J. Cell Biol. 2014, 93, 388-395. [CrossRef]

89. Jawhari, A.U.; Buda, A.; Jenkins, M.; Shehzad, K.; Sarraf, C.; Noda, M.; Farthing, M.J.; Pignatelli, M.; Adams, J.C. Fascin, an actin-bundling protein, modulates colonic epithelial cell invasiveness and differentiation in vitro. Am. J. Pathol. 2003, 162, 69-80. [CrossRef]

90. Kanda, Y.; Kawaguchi, T.; Kuramitsu, Y.; Kitagawa, T.; Kobayashi, T.; Takahashi, N.; Tazawa, H.; Habelhah, H.; Hamada, J.; Kobayashi, M.; et al. Fascin regulates chronic inflammation-related human colon carcinogenesis by inhibiting cell anoikis. Proteomics 2014, 14, 1031-1041. [CrossRef]

91. Hashimoto, Y.; Parsons, M.; Adams, J.C. Dual actin-bundling and protein kinase C-binding activities of fascin regulate carcinoma cell migration downstream of Rac and contribute to metastasis. Mol. Biol. Cell 2007, 18, 4591-4602. [CrossRef]

92. Chen, M.B.; Wei, M.X.; Han, J.Y.; Wu, X.Y.; Li, C.; Wang, J.; Shen, W.; Lu, P.H. MicroRNA-451 regulates AMPK/mTORC1 signaling and fascin1 expression in HT-29 colorectal cancer. Cell Signal. 2014, 26, 102-109. [CrossRef]

93. Montoro-García, S.; Alburquerque-González, B.; Bernabé-García, Á.; Bernabé-García, M.; Rodrigues, P.C.; den-Haan, H.; Luque, I.; Nicolás, F.J.; Pérez-Sánchez, H.; Cayuela, M.L.; et al. Novel anti-invasive properties of a Fascin1 inhibitor on colorectal cancer cells. J. Mol. Med. 2020, 98, 383-394. [CrossRef]

94. Huang, F.K.; Han, S.; Xing, B.; Huang, J.; Liu, B.; Bordeleau, F.; Reinhart-King, C.A.; Zhang, J.J.; Huang, X.Y. Targeted inhibition of fascin function blocks tumour invasion and metastatic colonization. Nat. Commun. 2015, 6, 7465. [CrossRef] 
95. Mahmoud, A.; Elkhalifa, D.; Alali, F.; Al Moustafa, A.E.; Khalil, A. Novel Polymethoxylated Chalcones as Potential Compounds Against KRAS-Mutant Colorectal Cancers. Curr. Pharm. Des. 2020, 26, 1622-1633. [CrossRef]

96. Alburquerque-González, B.; Bernabé-García, M.; Montoro-García, S.; Bernabé-García, Á.; Rodrigues, P.C.; Ruiz-Sanz, J.; LópezCalderón, F.F.; Luque, I.; Nicolas, F.J.; Cayuela, M.L.; et al. New role of the antidepressant imipramine as a Fascin1 inhibitor in colorectal cancer cells. Exp. Mol. Med. 2020, 52, 281-292. [CrossRef]

97. Walker, A.J.; Card, T.; Bates, T.E.; Muir, K. Tricyclic antidepressants and the incidence of certain cancers: A study using the GPRD. Br. J. Cancer 2011, 104, 193-197. [CrossRef]

98. Alburquerque-González, B.; Bernabé-García, Á.; Bernabé-García, M.; Ruiz-Sanz, J.; López-Calderón, F.F.; Gonnelli, L.; Banci, L.; Peña-García, J.; Luque, I.; Nicolás, F.J.; et al. The FDA-Approved Antiviral Raltegravir Inhibits Fascin1-Dependent Invasion of Colorectal Tumor Cells In Vitro and In Vivo. Cancers 2021, 13, 861. [CrossRef] [PubMed]

99. Khan, A.; Fan, K.; Sun, N.; Yin, W.; Sun, Y.; Sun, P.; Jahejo, A.R.; Li, H. Recombinant porcine NK-lysin inhibits the invasion of hepatocellular carcinoma cells in vitro. Int. J. Biol. Macromol. 2019, 140, 1249-1259. [CrossRef]

100. Elewa, M.A.; Al-Gayyar, M.M.; Schaalan, M.F.; Abd El Galil, K.H.; Ebrahim, M.A.; El-Shishtawy, M.M. Hepatoprotective and anti-tumor effects of targeting MMP-9 in hepatocellular carcinoma and its relation to vascular invasion markers. Clin. Exp. Metastasis 2015, 32, 479-493. [CrossRef]

101. Schenk, M.; Aykut, B.; Teske, C.; Giese, N.A.; Weitz, J.; Welsch, T. Salinomycin inhibits growth of pancreatic cancer and cancer cell migration by disruption of actin stress fiber integrity. Cancer Lett. 2015, 358, 161-169. [CrossRef]

102. Anderson, S.; Poudel, K.R.; Roh-Johnson, M.; Brabletz, T.; Yu, M.; Borenstein-Auerbach, N.; Grady, W.N.; Bai, J.; Moens, C.B.; Eisenman, R.N.; et al. MYC-nick promotes cell migration by inducing fascin expression and Cdc42 activation. Proc. Natl. Acad. Sci. USA 2016, 113, E5481-E5490. [CrossRef]

103. Conacci-Sorrell, M.; Ngouenet, C.; Anderson, S.; Brabletz, T.; Eisenman, R.N. Stress-induced cleavage of Myc promotes cancer cell survival. Genes Dev. 2014, 28, 689-707. [CrossRef] [PubMed]

104. Sui, X.; Zhu, J.; Tang, H.; Wang, C.; Zhou, J.; Han, W.; Wang, X.; Fang, Y.; Xu, Y.; Li, D.; et al. p53 controls colorectal cancer cell invasion by inhibiting the NF-kB-mediated activation of Fascin. Oncotarget 2015, 6, 22869-22879. [CrossRef] [PubMed]

105. Ou, C.; Sun, Z.; He, X.; Li, X.; Fan, S.; Zheng, X.; Peng, Q.; Li, G.; Li, X.; Ma, J. Targeting YAP1/LINC00152/FSCN1 Signaling Axis Prevents the Progression of Colorectal Cancer. Adv. Sci. 2020, 7, 1901380. [CrossRef]

106. Yu, S.; Xie, H.; Zhang, J.; Wang, D.; Song, Y.; Zhang, S.; Zheng, S.; Wang, J. MicroRNA-663 suppresses the proliferation and invasion of colorectal cancer cells by directly targeting FSCN1. Mol. Med. Rep. 2017, 16, 9707-9714. [CrossRef] [PubMed]

107. Feng, Y.; Zhu, J.; Ou, C.; Deng, Z.; Chen, M.; Huang, W.; Li, L. MicroRNA-145 inhibits tumour growth and metastasis in colorectal cancer by targeting fascin-1. Br. J. Cancer 2014, 110, 2300-2309. [CrossRef] [PubMed]

108. Wan, T.M.; Lam, C.S.; Ng, L.; Chow, A.K.; Wong, S.K.; Li, H.S.; Man, J.H.; Lo, O.S.; Foo, D.; Cheung, A.; et al. The clinicopathological significance of miR-133a in colorectal cancer. Dis. Markers 2014, 2014, 919283. [CrossRef]

109. Zheng, K.; Liu, W.; Liu, Y.; Jiang, C.; Qian, Q. MicroRNA-133a suppresses colorectal cancer cell invasion by targeting Fascin1. Oncol. Lett. 2015, 9, 869-874. [CrossRef]

110. Parsons, M.; Adams, J.C. Rac regulates the interaction of fascin with protein kinase C in cell migration. J. Cell Sci. 2008, 121, 2805-2813. [CrossRef]

111. Liu, L.; Zhao, L.; Zhang, Y.; Zhang, Q.; Ding, Y. Proteomic analysis of Tiam1-mediated metastasis in colorectal cancer. Cell Biol. Int. 2007, 31, 805-814. [CrossRef]

112. Hayashi, Y.; Osanai, M.; Lee, G.H. Fascin-1 expression correlates with repression of E-cadherin expression in hepatocellular carcinoma cells and augments their invasiveness in combination with matrix metalloproteinases. Cancer Sci. 2011, 102, 1228-1235. [CrossRef]

113. Radović, S.; Dorić, M.; Zujo, H.; Hukić, A.; Kuskunović, S.; Babić, M.; Tomić, I. Interdigitating dendritic cell sarcoma of the liver and lung: A case report with morphohological and immunohistochemical features of tumor. Bosn. J. Basic Med. Sci. 2012, 12, 203-206. [CrossRef]

114. Zhang, Y.; Lu, Y.; Zhang, C.; Huang, D.; Wu, W.; Zhang, Y.; Shen, J.; Cai, Y.; Chen, W.; Yao, W. FSCN-1 increases doxorubicin resistance in hepatocellular carcinoma through promotion of epithelial-mesenchymal transition. Int. J. Oncol. 2018, 52, 1455-1464. [CrossRef]

115. Kim, S.H.; Kim, Y.; Kim, M.; Kim, D.S.; Lee, S.C.; Chi, S.W.; Lee, D.H.; Park, S.G.; Park, B.C.; Bae, K.H.; et al. Comparative proteomic analysis of mouse melanoma cell line B16, a metastatic descendant B16F10, and B16 overexpressing the metastasisassociated tyrosine phosphatase PRL-3. Oncol. Res. 2009, 17, 601-612. [CrossRef]

116. Huang, J.; Tang, Y.; Zou, X.; Lu, Y.; She, S.; Zhang, W.; Ren, H.; Yang, Y.; Hu, H. Identification of the fatty acid synthase interaction network via iTRAQ-based proteomics indicates the potential molecular mechanisms of liver cancer metastasis. Cancer Cell Int. 2020, 20, 332. [CrossRef] [PubMed]

117. Li, Y.Y.; Shi, Z.M.; Yu, X.T.; Feng, P.; Wang, X.J. The effects of urotensin II on migration and invasion are mediated by NADPH oxidase-derived reactive oxygen species through the c-Jun N-terminal kinase pathway in human hepatoma cells. Peptides 2017, 88, 106-114. [CrossRef] [PubMed]

118. Liu, Y.; Hong, W.; Zhou, C.; Jiang, Z.; Wang, G.; Wei, G.; Li, X. miR-539 inhibits FSCN1 expression and suppresses hepatocellular carcinoma migration and invasion. Oncol. Rep. 2017, 37, 2593-2602. [CrossRef] 
119. Wang, G.; Zhu, S.; Gu, Y.; Chen, Q.; Liu, X.; Fu, H. MicroRNA-145 and MicroRNA-133a Inhibited Proliferation, Migration, and Invasion, While Promoted Apoptosis in Hepatocellular Carcinoma Cells Via Targeting FSCN1. Dig. Dis. Sci. 2015, 60, 3044-3052. [CrossRef] [PubMed]

120. Iacobuzio-Donahue, C.A.; Ashfaq, R.; Maitra, A.; Adsay, N.V.; Shen-Ong, G.L.; Berg, K.; Hollingsworth, M.A.; Cameron, J.L.; Yeo, C.J.; Kern, S.E.; et al. Highly expressed genes in pancreatic ductal adenocarcinomas: A comprehensive characterization and comparison of the transcription profiles obtained from three major technologies. Cancer Res. 2003, 63, 8614-8622. [PubMed]

121. Date, K.; Okabayashi, T.; Shima, Y.; Iwata, J.; Sumiyoshi, T.; Kozuki, A.; Morita, S.; Hata, Y.; Noda, Y.; Nishioka, A.; et al. Clinicopathological features and surgical outcomes of intraductal tubulopapillary neoplasm of the pancreas: A systematic review. Langenbeck's Arch. Surg. 2016, 401, 439-447. [CrossRef]

122. Yamaguchi, H.; Inoue, T.; Eguchi, T.; Miyasaka, Y.; Ohuchida, K.; Mizumoto, K.; Yamada, T.; Yamaguchi, K.; Tanaka, M.; Tsuneyoshi, M. Fascin overexpression in intraductal papillary mucinous neoplasms (adenomas, borderline neoplasms, and carcinomas) of the pancreas, correlated with increased histological grade. Mod. Pathol. 2007, 20, 552-561. [CrossRef] [PubMed]

123. Cao, D.; Maitra, A.; Saavedra, J.A.; Klimstra, D.S.; Adsay, N.V.; Hruban, R.H. Expression of novel markers of pancreatic ductal adenocarcinoma in pancreatic nonductal neoplasms: Additional evidence of different genetic pathways. Mod. Pathol. 2005, 18, 752-761. [CrossRef] [PubMed]

124. Shen, S.C.; Wu, C.C.; Ng, K.F.; Wu, R.C.; Chen, H.M.; Chen, T.C. Follicular dendritic cell sarcoma mimicking giant cell carcinoma of the pancreas. Pathol. Int. 2006, 56, 466-470. [CrossRef]

125. Lu, Z.; Hu, L.; Evers, S.; Chen, J.; Shen, Y. Differential expression profiling of human pancreatic adenocarcinoma and healthy pancreatic tissue. Proteomics 2004, 4, 3975-3988. [CrossRef] [PubMed]

126. Xu, Y.F.; Yu, S.N.; Lu, Z.H.; Liu, J.P.; Chen, J. Fascin promotes the motility and invasiveness of pancreatic cancer cells. World J. Gastroenterol. 2011, 17, 4470-4478. [CrossRef] [PubMed]

127. Yoshida, K.; Kuramitsu, Y.; Murakami, K.; Ryozawa, S.; Taba, K.; Kaino, S.; Zhang, X.; Sakaida, I.; Nakamura, K. Proteomic differential display analysis for TS-1-resistant and -sensitive pancreatic cancer cells using two-dimensional gel electrophoresis and mass spectrometry. Anticancer Res. 2011, 31, 2103-2108. [PubMed]

128. Qian, C.J.; Chen, Y.Y.; Zhang, X.; Liu, F.Q.; Yue, T.T.; Ye, B.; Yao, J. Notch4 inhibition reduces migration and invasion and enhances sensitivity to docetaxel by inhibiting Akt/fascin in pancreatic cancer cells. Oncol. Lett. 2016, 12, 3499-3505. [CrossRef] [PubMed]

129. Qin, Y.; Dang, X.; Li, W.; Ma, Q. miR-133a functions as a tumor suppressor and directly targets FSCN1 in pancreatic cancer. Oncol. Res. 2013, 21, 353-363. [CrossRef] 